TYPE YOUR LISTENERSHIP:

AN EXPLORATION OF LISTENERSHIP IN INSTANT MESSAGES

\author{
A Thesis \\ submitted to the Faculty of the \\ Graduate School of Arts and Sciences \\ of Georgetown University \\ in partial fulfillment of the requirements for the \\ degree of \\ Master of Arts \\ in Linguistics
}

By

Hanwool Choe, B.A.

Washington, DC

April 15, 2015 
Copyright 2015 by Hanwool Choe All Rights Reserved 


\title{
TYPE YOUR LISTENERSHIP: AN EXPLORATION OF LISTENERSHIP IN INSTANT MESSAGES
}

Hanwool Choe, B.A.

\author{
Thesis Advisor: Deborah F. Tannen, Ph.D.
}

\begin{abstract}
This study investigates listenership in Instant Messages among five Korean females including the researcher via KakaoTalk messenger (KakaoTalk), a free instant messaging application popular in South Korea. The goal is 1) to explore listenership practices in written digital discourse; 2) to elucidate the vital role of listenership in the co-construction of digital conversation; and 3) to see how the medium KakaoTalk, age-related social relations among friends, and the Korean language are intertwined to express listenership in Instant Messages.

The study extends previous research on minimal responses, conversational styles, and framing phenomena in spoken conversation to written digital discourse. Specifically, 1) I demonstrate that minimal responses vary according to age, and listeners repeat them and change the forms of minimal responses as support work; 2) building on Tannen's (2005) concept of machine gun questions, I identify what I call machine gun listenership, consisting of both machine gun questions as well as machine gun answers to indicate enthusiasm and interest in speakers' talk; and 3) drawing on theories of framing including Tannen and Wallat (1987), Tannen (2006), and Gordon (2008, 2009), I show how listeners use framing phenomena such as reframing, discursive frame shifts, re-alignment toward previous messages, and rekeying through contextualization cues like parentheses and an animated sticker. I also suggest a system of primary and secondary floors that helps illuminate the way participants shift between speaker and listener roles. This study thus extends concepts and insights
\end{abstract}


developed in the study of listenership in spoken interaction to written digital conversation conducted on instant messaging. 


\section{ACKNOWLEDGEMENTS}

A year ago, while I was reading a chapter, Repetition in conversation in Deborah Tannen's book, Talking voices, listenership struck me as an interesting area for study and I went straight to Dr. Tannen's office to let her know my final paper topic for her Discourse and Social Media class. I still remember that I tried to explain to her, with little success, my vague and wild ideas about listenership. Later, in response to a paper I wrote for that class, she wrote a comment that "Reading this I felt I understood your interest in listenership." Ever since then, she has become my thesis advisor and continuously supported me to finish this work. I owe an enormous debt of gratitude to Dr. Tannen not only for her thorough feedback at all stages in the process but also for her support and encouragement. I truly admire her commitment to high standards and her unfailing devotion to helping students succeed. I would also like to thank her for polishing my clumsy English. It is my honor to have had her as my thesis advisor. I offer my sincere appreciation for these learning opportunities afforded me because of her.

I also offer my sincere gratitude to my professors, who have helped me to stretch and grow as a linguist: Dr. Frederick Erickson, Dr. Elena Herburger, Dr. Natalie Schilling, Dr. Jennifer Sclafani, Dr. Shaligram Shukla, and Dr. Ruth Wodak. A special thank you goes to Dr. Cynthia Gordon, who guided me through her articles and took the time to discuss framing with me during her office hours.

My heartfelt gratitude is extended to my academic advisors, who have enabled me to grow academically and professionally: Dr. Heidi Hamilton, and the Masters of Arts in Language \& Communication (MLC) directors; Dr. Anastasia Nylund and Dr. Anna Trester.

I must thank my dearest friends: my lovely ABC trio - Lauren Adams and Kristine Bundschuh (and C is me!); my MLC thesis seminar classmates - Glenn Abastillas, Jehan Al-mahmoud, and Gwynne Mapes; my MLC cohort - Paige Arthur, Matthew Mermel, Andrea Precio, Hannah Sullivan, and Amanda Tolbert; my social media seminar classmates - Nazir Harb, Didem Ikizoglu, Adrienne Isaac, and Jeremy Wegner; Yuka Akiyama, Jinsok Lee, Todd Mckay, Sylvia Sierra, and Sakol Suethanapornkul. A special thank you goes out to YoonKyung Ohm, who generously helped to translate my data, and Andrew Chester, who kindly proofread my thesis and gave me insightful advice on how to explain the Korean grammar and phonology in English.

A special thank you also goes to my dearest fellow Korean Fulbrighters: Naeun Gu, Young Hwang, Mi Jeong Lee, and Haejeong Yoon for all the support and friendship you have given me. I am always wishing the best for your academic achievements. Even though we live in 
different cities and different states, I hope we can get together someday, somewhere in the United States!

I also wish to express thanks to my D.C. Fulbright friends, especially National Capital Area of Chapters board members: Rachael Aldridge, Gregory Cooper, James Feinstein, Irina Hobbs, Paloma Navas, Hyesung Oh, Seth Oppenheim, Cris Ramon, John Rios, Raul Saraivia, Mark Vlasic, Sarah Watson, and Tara Woods. The board meeting was my monthly sweet exit where I could take a break from endless writing.

I also appreciate the Fulbright program, which has offered me financial supports for my Masters studies as well as opened my eyes to the world.

Additionally, appreciation is expressed to Lauinger Library where I have spent my time writing this thesis since September 2014; you have always offered me cold water, lights, printers, and computers, although they sometimes shut down out of the blue and gave me a heart attack. And I also want to thank KakaoTalk messenger, which has become the center of my research and always connected me to friends and family.

Finally, my deepest expression of appreciation goes to my caring, loving, and supportive family: my uncles, aunts, cousins, and last but absolutely not least, my parents and my sister. Even though we are apart, you always send me continuous encouragement through KakaoTalk. You are always there for me whenever I feel miserable and discouraged. Without your boundless love and support, I could not have made it. 


\section{TABLe Of CONTEnTS}

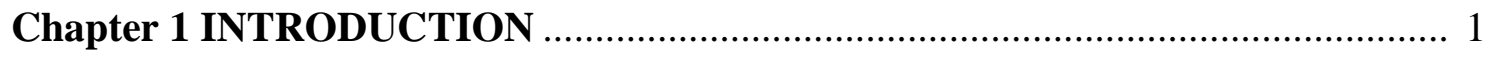

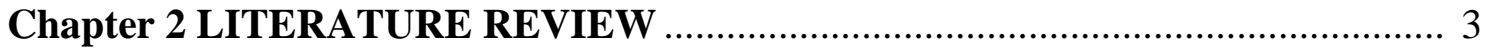

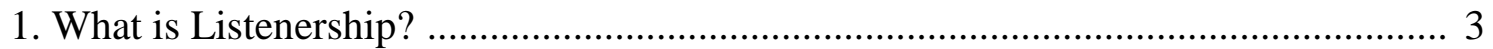

2. Multiple Perspectives on Listenership ............................................................. 8

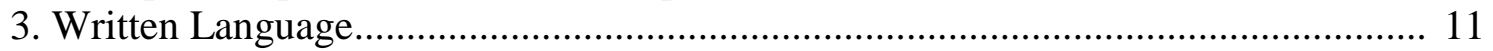

Chapter 3 BACKGROUND INFORMATION ............................................... 14

1. Korean Alphabet and Language ................................................................. 14

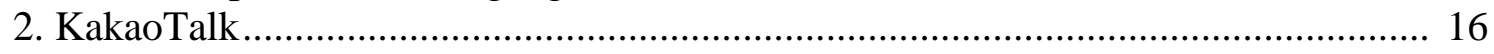

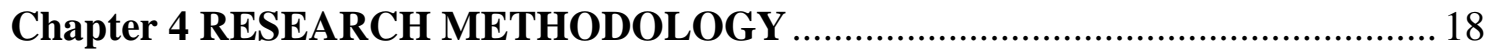

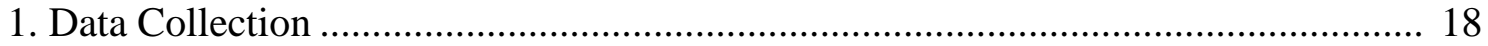

2. Profiles of Conversation Participants........................................................... 19

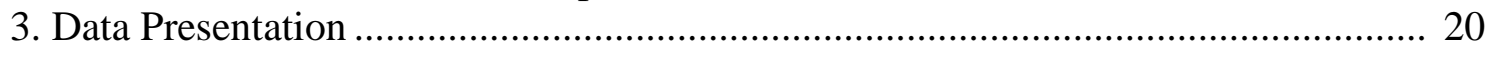

Chapter 5 LISTENERSHIP IN DIGITAL DISCOURS ................................ 21

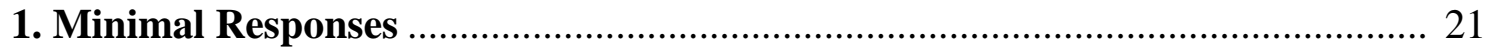

1.1. Simplified Minimal Response between Participants of the Same Age................. 22

1.2. Informal Minimal Response by Older Participants ......................................... 25

1.3. Honorific Minimal Response by a Younger Participant..................................... 28

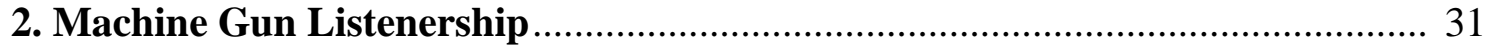

2.1. Machine Gun Questions............................................................................. 33

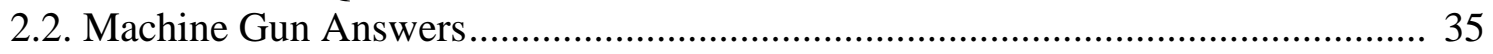

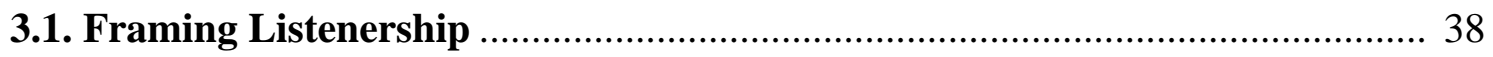

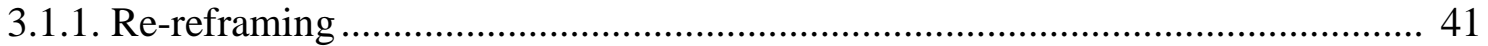

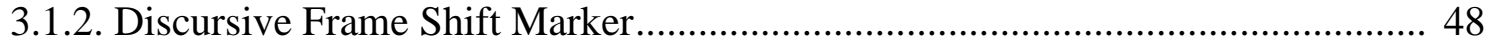

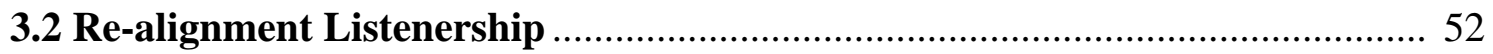

3.2.1. Re-alignment through Voice Quality ........................................................ 52

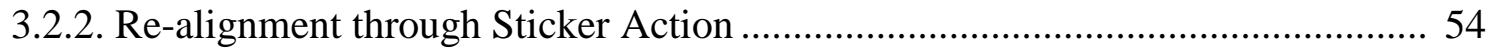

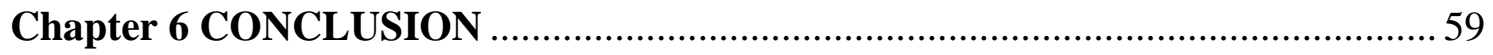

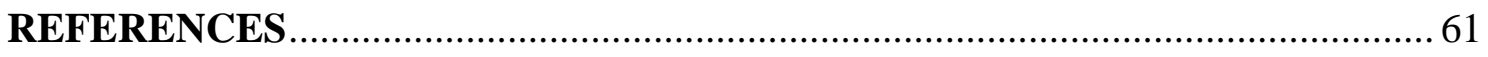




\section{Chapter 1 INTRODUCTION}

M. Goodwin (1996) notes that "much research on discourse deals largely with the actions of the speaker" (77). It is true that speakers are important in producing talk, but listeners figure prominently in communication as well. Listeners do not sit quietly for attentive listening. They also talk and make physical movements during communication, and these verbal and non-verbal actions greatly contribute to the construction of talk. C. Goodwin (1986) finds that the meaning of talk emerges from a collaborative process of interaction where audiences as well as speakers play a very active role together. Indeed, previous studies have demonstrated the influence of listenership in different areas, for example, in a sales encounter (Castleberry and Shepherd 1993, Ramsey and Sohi 1997, Comer and Drollinger 1999, De Ruyter and Wetzels 2000, etc.), in language learning (Kellerman 1992, Rost 2013, etc.), and in interactions (Bavelas, Coates, and Johnson 2000, 2002, Richardson and Dale 2005, etc.). Those studies have suggested that understanding what listeners are doing must be a key to understanding communication.

Then, how can listeners show their listenership in Instant Messages where written language is the means of communication? Instant Messages are "direct, immediate, and casual online contact" (Schiano et al. 2002) and this nature of Instant Messages enables people to write as if they talked face-to-face. I investigate listenership in Instant Messages among five Korean females including myself via KakaoTalk 1) to explore listenership practices in written digital discourse; 2 ) to elucidate the vital role of listenership in the co-construction of digital conversation; and 3) to see how the medium, KakaoTalk, age-related social relations among friends, and the Korean language are intertwined to express listenership in Instant Messages. 
The organization of this paper is as follows. I begin with my definition of listeners and listenership through a new floor system that I propose, to clearly justify my characterization of listenership and listeners. I then review the literature to explore multiple perspectives on listenership. Also, I examine features of written language to highlight Instant Messages as a hybrid medium between written language and spoken language. Next, for a better understanding of the conversations presented here, I give an overview of the core principles of the Korean alphabet - 한글 / hangul/ and language including Korean syllable structures. Then I explain KakaoTalk where the conversations took place. After describing data collection, profiles of conversation participants, and data presentation, I present examples of different types of listenership, each of which includes its own literature review, in three sections: 1) minimal responses, 2) machine gun listenership, and 3) framing listenership. Specifically, 1) I demonstrate that minimal responses vary according to age, and listeners repeat them and change the forms of minimal responses as support work; 2) building on Tannen’s (2005) concept of machine gun questions, I identify what I call machine gun listenership, consisting of both machine gun questions as well as machine gun answers to indicate enthusiasm and interest in speakers' talk; and 3) drawing on theories of framing including Tannen and Wallat (1987), Tannen (2006), and Gordon (2008, 2009), I show how listeners use framing phenomena such as reframing; discursive frame shifts; re-alignment toward previous messages; and rekeying through contextualization cues like parentheses and an animated sticker. Then, I summarize the findings of this study and highlight the importance of listeners as coconstructors of written talk and the ways in which written language reshapes spoken discourse phenomena and is used in listenership discourse. Finally I include a discussion of how this 
study contributes to broadening our understanding of listeners and listenership in written digital interaction.

\section{CHAPter 2 Literature REVIEW}

\section{What is Listenership?}

Studies of listenership have been almost exclusively based on spoken communication. However, listenership is omnipresent whether the form of talk is written or spoken; for example, as we nod or say "mmhmm" as a sign of listenership in face-to-face interaction, we can also do it in writing, yet in different ways. One reason we tend to overlook listenership in written communication is probably because we intuitively perceive listenership as an action of "hearing." But hearing is only a part of listening activities, and based on what listeners are hearing, they make verbal and/or nonverbal moves to participate in the interaction.

Moreover, there is no term that covers the wide range of different listening activities; for instance, there are numerous terms to describe listeners' verbal and nonverbal activities including listenership (McCarthy 1996, Farr 2003, Tannen 2007), listening action (Erickson 1986), backchannel (Yngve 1970), listener responses (Maynard 1996), listening behavior (Hall 1969, Erickson 2010), minimal response (Fishman 1978, Coates 1986), receipt tokens (Heritage 1984, Gardner 1997), hearer signals (Bublitz 1988, Meyerhoff 1994), reactive tokens (Young and Lee 2004), signals of continued attention (Fries 1952), recognition (Rosenfeld 1966), assent terms (Schegloff 1972), and continuers (Schegloff 1982). Although what they share is attention to listeners' engagement with talk and speakers, each suggested term has its own approach and focus on an arbitrary and/or visual set of listening activities or is a general term widely used in and out of academia without being clearly defined. 
Also, we tend to approach listening activities with an intuitive awareness. To be specific, we usually associate listenership with what only listeners do and speakership with what only speakers do, but speakers and listeners are not fixed roles. They exist in the same people, at different times, which makes it hard to measure and distinguish such dynamic discursive roles (speakers and listeners) and activities (speaking and listening). More importantly, we should be aware that listeners can talk and speakers can listen at the same time, and that talking as a listening activity is different from talking as a speaking activity.

For these reasons, it is meaningful to define to what extent utterances are considered as listenership and who are called listeners, which can be applicable to any type of communication. This paper will use listenership as an umbrella term to refer to verbal and nonverbal listeners' activities.

To explain listener participation in conversation, I adapt the notion of floors. First, I define listenership as verbal and/or nonverbal responses. I emphasize responses here because listenership is reactive rather than proactive. Listenership cannot exist alone; it always needs input to exist. To get into more detail of this listenership operation, I first look at how the interaction plays out, which can be best described by Erickson's (2015) analogy of playing ping pong to the notion of floor. Floor is frequently understood as the place where a person gets a turn to talk. In interaction, people talk back and forth, so the floor goes back and forth like a ball when playing ping pong. In this ping pong communication, primary speakers commence talk by serving the ball and then listeners, or receivers, hit back the ball to the speakers to respond. Sacks, Schegloff, and Jefferson (1974) introduce a model for the turn-taking organization for conversation. According to them, a turn is allocated as one-speaker-at-a-time to "minimize gap and overlaps" between turns (704). Since then, different types of floor systems 
have been suggested, for example, Edelsky (1981), Shultz, Florio, and Erickson (1982), and Hiyashi (1991). Those floor systems mostly seek to identify multiple floors in interaction, but they differ with respect to the number of floors.

However, Jones and Thornborrow (2004) "shift the focus away from a notion of the conversational floor as a "turn" or as "speaking," and toward an account that treats "the floor" as a way of organizing whatever activity is going on at any given moment" (400) including “active listenership, incipiency (silence), interruption, simultaneous talk, multiple floors, and flexibility among them” (420). Their study reconceptualizes the floor as an activity type rather than a sequential organization of conversations, which allows us to expand the discussion of what is going on in interaction and consequently demonstrates "all present are involved in whatever activity is ongoing” (421).

The work of Jones and Thornborrow can shed light on the ping pong like interaction. In reality, interaction does not always happen with one single ball; it rather plays out with multiple balls simultaneously. Also once the interaction starts, 1) the server and the receiver all become hitters without distinction; 2) even if awaiting the balls for a moment, ping pong participants do not remain motionless; and 3) all can become both the server and the receiver at different times. Given the complexity of interaction, I propose an alternative floor model, which will unravel twisted threads of discursive activities, whereupon I ultimately define listenership utterances for this study.

In my floor model, there are two types of floors: the primary floor and the secondary floor. The primary floor is where people take the leading role to talk and the secondary floor is where people take the supporting role to talk, which appears in various forms such as overlapping, minimal response, asking and/or answering questions, or even silence. Speakers 
and listeners do not always occupy the primary floor and the secondary floor respectively; listeners can become primary floor-holders to talk but what they are doing on the primary floor should be defined as responding. As the term responding implies, what listeners need to access the primary floor is input, which can be prior utterances, topics, or situational frames made by primary speakers. Thus, when listeners get the primary floor and what is currently being said and/or done by listeners is under the influence of that prior input, they are still considered listeners, not speakers. While listeners are on the primary floor to respond, what speakers are doing on the secondary floor can be understood as the speakers' listenership, which is, I suggest, mutual listenership where listenership is oriented to each other. When current listeners, who talk on the primary floor, suggest new topical, discursive, or situational input, they are finally recognized as speakers. However, if current speakers, who are listening on the secondary floor, do this, the primary floor will be passed over to the current speakers and what they are doing is now called speakership, not listenership.

The following example illustrates how this floor system works in a naturally occurring KakaoTalk conversation.

\begin{tabular}{ll} 
& \multicolumn{1}{c}{ Feb 28, 2014, 5:00 PM } \\
& 아 뭔가뜨끈한거먹고싶다 \\
& Ah something hot eat-want \\
& Ah I want something warm and \\
filling
\end{tabular}

Feb 28, 2014, 5:04 PM

\begin{tabular}{|c|c|}
\hline 홍합팅 & $\mathrm{Me}$ \\
\hline Mussel Soup & \\
\hline Feb 28, 2014, 5:04 PM & \\
\hline $\begin{array}{l}\text { 우동 } \\
\text { Udon }\end{array}$ & $\mathrm{Me}$ \\
\hline
\end{tabular}


Feb 28, 2014, 5:04 PM

오 뎅탕

$\mathrm{Me} \quad 4$

Fishcake soup

Feb 28, 2014, 5:04 PM

사케

Sake*

$\mathrm{Me} \quad 5$

*Sake is a type of Japanese drink,

which people usually warm up before

drinking.

Feb 28, 2014, 5:04 PM

갑자기 본죽 먹고싶네

Suddenly Bon Porridge eat-want

I am craving rice porridge

from Bon Juk* in Korea

Me 6

*Bon Juk is the name of Korea's

franchised porridge restaurant.

Koreans eat rice porridge as comfort

Feb 28, 2014, 5:04 PM

food when it is cold or they are sick.

7 Mina

사켘ㅋㅋㅡ

Sake ヨココココ

Feb 28, 2014, 5:04 PM

Feb 28, 2014, 5:04 PM

참치야채죽 맛있눙데

장저림이랑

Tuna vegetables porridge

delicious Jangjorim-with

I love the porridge with

Me 8 canned tuna and vegetables, and Jangjorim*

*Jangjorim is a Korean side dish made of braised beef and eggs.

9 Mina

난호박죽..

I pumpkin porridge

I love pumpkin porridge...
Feb 28, 2014, 5:05 PM

헐 호박죽에 들어있는

떡같은거

Oh my god pumpkin porridge-at include rice cake-something-like

Oh my god I am dying for

those little rice balls in

pumpkin porridge

Based on the floor system, Mina is considered a primary speaker since she initiates this conversation on the primary floor, talking about her wish to have hot food in line 1, "Ah I want something warm and filling." As a primary listener, I respond to her talk by listing a series of 
hot foods, which I will call “machine gun answer listenership” later in my analysis, and make some comments about particular types of food. My messages are triggered by her talk. The influence of her talk is topical input, and further, my listenership expands her suggested topic, by talking about specific hot foods. That is why my discursive role is still a listener and what I am discursively doing is treated as listening. Conversely, Mina's discursive role is still recognized as a speaker. But what she is discursively doing can be summarized in two ways: first, she speaks on the primary floor at the beginning to initiate the conversation, and second, she listens on the secondary floor later to respond to my listenership; laughing in line 7, "Sake ヨココココ," and chiming in with me in line 9, "I love pumpkin porridge...," which I consider as her listenership toward my listenership, or mutual listenership.

It may seem that this floor system oversimplifies discursive phenomena but it enables us to identify conversation participants' discursive roles and what they are discursively doing, especially who are listeners and what they are discursively doing. Note that this floor system does not attempt to stratify discursive activities but rather to clarify what contributions listeners make to interaction and how listenership is shown. In summary, 1) listenership is responsive; 2) listeners and listenership (speakers and speakership too) can be situated in both the primary floor and the secondary floor; and 3) listenership can be performed by both listeners and speakers.

\section{Multiple Perspectives on Listenership}

Let us consider now what has been discussed in previous listenership studies. There has been a progression of opinions about listeners. Yngve (1970) first proposes a "back channel," through which listeners make responses while speakers own and talk through the main channel. His framework highlights listeners' activities but it implies that listeners are subordinate to 
speakers. Also, Goffman's (1981) notions of production format and participation framework draw a clear distinction between speakers and listeners (hearers, in his words). In production format, only a speaker contributes to speech production at talk as an animator, an author, and a principal. Listeners, in Goffman's participation framework, are those who are according to the roles they play in interaction: ratified (official), subdivided into addressed and unaddressed, and unratified (unofficial), subdivided into eavesdroppers and overhearers. These roles are assigned and identified by speakers based on visual criteria such as listeners' body orientation and physical distance between speakers and listeners.

Those studies somewhat underestimate the contributions that listeners make in interaction. In contrast, Hall (1969) addresses listening as a meaningful and productive discursive action in communication. Following Hall, Erickson's studies (1982, 1986, 2004) and Erickson and Shultz (1982) have been very influential in emphasizing listenership as an important element in interaction. For example, Erickson (1982) identifies how social interaction is constructed through topical cohesion and multiple floors, which are done by the collective action of speakers and listeners. Throughout videotaped academic advising conversations, Erickson and Shultz (1982) explain how different patterns of speaking and listening between people create uncomfortable moments. Erickson (1986) also demonstrates the ways in which participants' different culturally learned knowledge affects their listenership to one another through the observation that "talking with another person... is like climbing a tree that climbs back" (316). In Erickson (2004), he suggests that discourse is produced by speakers and listeners together under the ecology of their mutual influence. Within this ecology, each participant operates her or his own local time - kairos - and performs multiple action cues - largely speech prosody and body motion - what Gumperz (1982) called 
contextualization cues. Erickson claims that these contextualization cues "signal the timing of crucial functional moments in sequences of individual actions in a conversation in order that they can be done in a jointly articulated fashion rather than haphazardly" (8).

This mutual influence between speakers and listeners is what we can find in Duranti (1986). According to him, speakers and listeners (audience, in his words) are equals not because discursive roles are interchangeable but because speaking action is oriented toward and ratified by an audience. Haviland (1986) and Borker (1986) also note that the interplay between speakers and listeners contributes to the construction of talk. Additionally, Brenneis (1986) emphasizes listeners as the "critical interpretive and meaning-creating role" (339). Gumperz (1977) asserts that "conversing is rather like collaborating in the production of a play, where each person's contribution is constrained by what the others can do and what the audience will accept" (194). That is, interaction is made up of collaboration between speakers and listeners, who come under mutual influence, and the collaboration leads to successful communication.

Xudong (2009) groups the previous works on listenership into macro- and micro-levels: lumping and splitting approaches. According to Xudong, the lumping approach "treats as a single category or class a group of different forms of listener responses" (105) whereas the splitting approach, "mainly taken by conversational analysts, has examined some discrete listener response tokens in their sequential contexts" (111).

In fact, however, methodological tools used in listenership studies can be addressed in greater detail. Corpus-based works such as McCarthy (1996) and Murphy (2012), and experiments-based works such as Li (2006) and Bavelas, Coates, and Johnson (2000) find certain patterns of listenership in a quantitative way. In discourse analysis studies, traditional play script transcripts are prevalently used to analyze functional features of listenership in 
interaction such as placement, sequential organization, and so on. (Schegloff 1982, Jefferson 1984, Gardner 1997, 2007, Young and Lee 2004). However, Erickson (2010) points out some limitations that such play script transcripts have, in that they "arrange interaction around the sequential progress of talk and obscure relations of mutual influence between the speaking behavior of speakers and the listening behavior of listeners" (243). Also, C. Goodwin’s (1979, 1984, 2000, 2002, etc.) research underlines that analysis of utterances cannot be isolated from paralinguistic phenomena in interaction where both verbal and nonverbal actions naturally emerge together. As alternatives to the conventional transcripts, Erickson adapts musical scores into the transcripts (Erickson 1982). Such multimodal analysis, like context analysis, enables all possible communicative capacity of listeners to be accounted for visually as well as auditorially (Kendon 1990, Erickson 2004). Exploring listenership in Instant Messages will be different in many ways. This study is, however, still relevant to multimodal aspects of interaction because the study aims to find alternative listenership strategies that listeners in Instant Messages use to replace paralinguistic and phonological phenomena in interaction.

So far, we have dwelled on various perspectives on listenership. Now, I will examine how the perception and use of written language has evolved.

\section{Written Language}

Chafe $(1982,1985,1986)$ notes that writing is typically performed in social isolation, whereas speaking typically occurs in a face-to-face interactive situation. In observing differences between writing and speaking, he associates writing with integration, and speaking with involvement respectively. In written language there is a time gap between writing and reading, which makes it impossible for writers to have immediate interaction with readers and vice versa. Spoken language, meanwhile, has spurt-like features, made possible by real-time 
interaction with the audience. Ochs (1979) distinguishes spoken and written language by whether it is planned or not.

Many other studies have also presented differences between written and spoken language such as Cayer and Sacks (1979), Blankenship (1974), and Einhorn (1978). However, these contrasting perspectives have come to admit the interplay between written language and spoken language. For example, Horowitz and Newman (1964) asked undergraduates to talk and write about the same topics and found some differences between writing and speaking but Horowitz and Berkowitz (1964) found that the faster people write, the more they write in a spoken-like way. Their findings still provide significant insight into thinking about why people show more spoken-like features when they talk through Instant Messages. Also, there are a number of studies investigating the influence of speaking on writing such as Barron (1985), Danielewicz and Chafe (1985), Fasold (1982), and Whiteman (1981[2013]), as cited in Chafe and Tannen (1986). Tannen (1982) also argues that spokenness and writtenness are not isolated from each other. She demonstrates that features identified as spoken language are used in written narratives such as fiction. Depending on discursive goals and genre, written language and spoken language can have much in common. Biber (1988) also challenges the binary distinction between speech and writing, arguing that they can be flexibly situated along multiple dimensions.

This insight into the mutual relation between written and spoken language has been stimulated by the emergence of Electronically-Mediated Communication (EMC). EMC is defined as "the use of written language on hardware platforms such as computers and mobile phones" (Baron and Ling 2011:47). Crystal (1995) argues that EMC blurs the distinction between speech and writing and constitutes a mixed medium of speaking and writing. In EMC, 
people often write as if they were speaking face-to-face to each other. As one kind of EMC, Instant Messages strengthen and enlarge this blurred relationship between speaking and writing. It would be more accurate to say that Instant Messages are the most hybrid medium of communication between written and spoken language. Instant Messages require people to be online at the same time like spoken communication. Its semi-synchronicity is the most important way in which it is spoken-like written language in communication: Ko (1996) and Werry (1996) find that Instant Messages tend to exhibit more oral features and Baron (2004) reports that the use of contracted forms (e.g., don't) were more frequent than that of noncontracted forms (e.g., do not) in Instant Messages even though contractions are more common in spoken language. In addition to that, Instant Messages enable people to compensate and embellish prosodic and paralinguistic elements in alternative ways. For instance, Tannen (2013) shows people use capitalization (e.g., I MISS YOU TOO), repeated punctuation marks (e.g., cool!!!!!!!!!!), and repetition of letters (e.g., Hiiiiiii) as enthusiasm markers to emphasize their unmarked enthusiasm and/or interests. Dresner and Herring (2010) find that emoticons such as a smiley face : $)^{1}$ and a wink ; $)^{2}$ are used as textual indications of illocutionary force in interaction.

In summary, written language in Instant Messages includes many features of spoken language due to the nature of the EMC environment. Thus, listenership in Instant Messages can contain and adapt discursive phenomena of spoken communication.

Next, background information will be addressed, which helps readers understand the Korean Instant Messages analyzed here.

\footnotetext{
${ }^{1}$ A colon represents sideways eyes and a close bracket represents a sideways smile.

${ }^{2}$ A semi colon represents a sideways wink and a close bracket represents a sideways smile.
} 


\section{CHAPTER 3 BACKGROUND INFORMATION}

\section{Korean Alphabet and Language}

The Korean writing system, called 한글 / hangul/, basically consists of 14 consonants and 10 vowels, as seen below. It was created by King Sejong (1397-1450) during the Joseon Dynasty in 1443, according to Song (2005: 45).

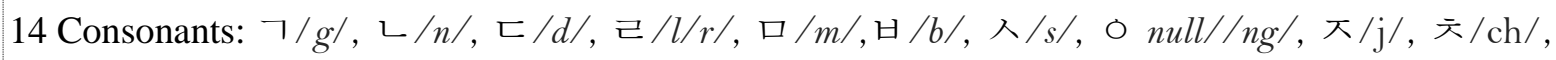

$$
\exists / \mathrm{k} /, \mathrm{E} / \mathrm{t} /, \text { 표/p/, 해 } \mathrm{h} /
$$

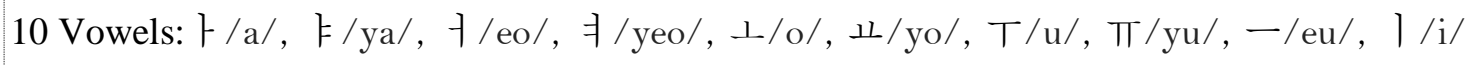

In fact, it is correct to say that there are as many as forty letters in all. Basic consonants and vowels are combined together respectively to make five doubling consonants $(77 / \mathrm{kk} /$, ᄃ[ / tt/, 부/pp/, 从/ss/, 저/jj/), which are tensed stops, and eleven complex vowels ( H/ae/, H/yae/, 키/e/, 케/ye/, 나/wa/, 꺼/wo/, ㄱ/ui/, 기/oe/, 꺼/wi/, 내/wae/, 께/we/). For example, the doubling consonant, $77 / \mathrm{kk} /$, is made up of two $\neg / \mathrm{g} /(\neg+\neg=77)$ and the complex vowel, 키/ye/, is a combination of $\exists /$ yeo/ and $1 / \mathrm{i} /$. The following is the 한글/hangul/ in the complete set.

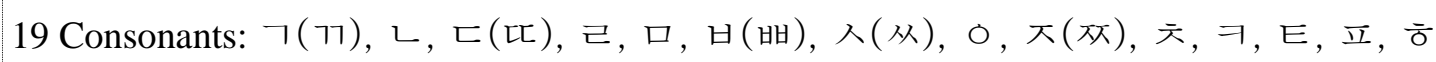

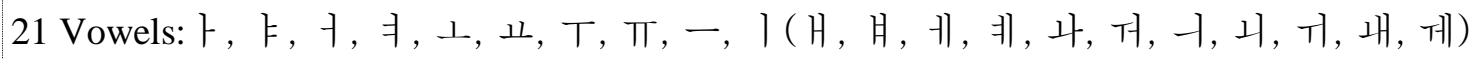

The orthography of Korean is a syllable-based system. In Korean, consonants and vowels are grouped together to form a "block" and each block corresponds to one syllable. Although the Korean writing system is written from left to right like English, when it comes to making a block, the direction goes top-down. The basic syllable structure in Korean is $(\mathrm{C}) \mathrm{V}(\mathrm{C})$ including V, CV, VC, and CVC, where C and V stand for consonant and vowel respectively. For 
instance, in a CVC syllable structure, it consists of three parts: initial, medial, and final part. The medial part is always a vowel. The two parts before and after the medial vowel are syllable-initial and syllable-final consonants respectively. As an example of CVC structure, the informal minimal response, 응 / eung/ has the CVC structure. It consists of word initial consonant $\bigcirc(\mathrm{C})$, medial vowel, $-(\mathrm{V})$, and the final consonant $O(\mathrm{C})$ again. As mentioned earlier, to make a block, it should be written like 응, not $\mathrm{O}-\mathrm{O}$.

Note that when it comes to phonology, 응 /eung/ has the VC structure. It is because the consonant, $\circ$ [ieung], has two variants: null and /ng/. When the consonant, $\circ$ [ieung], is an initial consonant, it is not pronounced. In final position, it has the / $\mathrm{ng} / \mathrm{sound}$. In the syllable structure, an initial written consonant is mandatory, however occasionally this initial consonant is not pronounced. When there is no initial consonant such as V or VC, the initial consonant's position is filled with the consonant, $\bigcirc$ [ieung], acting as a placeholder. Therefore, in the minimal response, 응 /eung/, the initial $\circ$ [ieung] does not have the usual phonetic value of $/ \mathrm{ng} /$. This study will only address the written syllable structure.

In digital discourse like Instant Messages, Koreans, mostly those of the younger generation, tend to shorten words or use Korean letters as pictograms. For instance, they replace an informal minimal response, 응 /eung/, with the consonant, $\bigcirc$ [ieung]. Two Korean consonants, $\exists / \mathrm{k} /$ and $\bar{\delta} / \mathrm{h} /$, which appear quite often throughout the excerpts, are used most of the time as laughter. If you type $\exists$ and $\overline{0}$ more than three times, $コ コ コ$ or $\overline{0} \overline{0}$ for instance, it usually symbolizes laughter, which is equivalent to LOL (Laugh Out Loud) or ROFL (Rolling On Floor Laughing) in English EMC acronyms. People sometimes mix them 
like $コ コ \bar{o}$ in any order. But, these Korean-lettered laughing pictograms can mean more than laughing including mixed feelings, depending on the contexts. Two Korean vowels, T /yu/ and $T / \mathrm{u} /$ are also used often to indicate crying because it looks like a tear coming out of an eye, thus semantically equivalent to a western style crying emoticon, :', which consists of a colon for eyes, an apostrophe for a tear, and a left parenthesis for a sad mouth. Koreans widely use them in pairs such as $\pi \pi$ and $T \top$ but to emphasize their sad feelings, Koreans type as many as they want like $\pi \pi \pi \pi \pi \pi$, $T \top 丁 \top T \top$, or $T \top \pi$ together in any order.

\section{KakaoTalk}

KakaoTalk is a Korean free instant messaging application widely used in South Korea by smartphone users. A Bloomberg News journalist, Frier (2013), reports that South Korea has a smartphone penetration rate of 73 percent and of those people, 93 percent use the mobile messaging application, KakaoTalk. People can chat one-on-one, or with an unlimited number of friends for free via KakaoTalk. KakaoTalk also provides many kinds of services that make it easier for people to communicate with others in real-time. For example, people can not only type but also send featured stickers ${ }^{3}$ and emoticons. Some stickers and emoticons are free but many are paid items which must be purchased in order to use. In addition, Voicetalk allows people to call other KakaoTalk users for free. KakaoTalk also automatically stores all written messages exchanged except the conversations via Voicetalk into its database so users have free access and can download their past conversation log files where they can find information about the date and time the message was sent, the name of the message sender, and the message content. In a chat room, there are always two columns: the left side, in white word bubbles,

\footnotetext{
${ }^{3}$ Stickers are larger scale emoticons, some of which include sound and /or animation.
} 
shows the messages received from other participants, and the right side, in yellow bubbles, shows the messages sent from you.

The message-read notification is one of the most salient features KakaoTalk has. This notification tells whether each message has been read by all participants, in the same manner as in several messaging services such as Facebook Messenger, LINE, What's app, and iMessage. KakaoTalk's message-read notification is always presented as a number at the end of each message; each number indicates the number of current participants that have not read that message. For example, figure 1 is a snapshot of my family's group chat room in KakaoTalk where there are four participants. I circle particular message-read notification numbers to explain; in line 1 , the number 4 indicates the total number of conversation participants. In line 10 where the latest message sent appears, the number 3 is displayed, meaning that the other three participants have not yet seen the message. As each participant reads the message, the number decreases. For instance, in line 6, the number is 1 , which shows that only one person has not read that message yet. When all participants have read the message, the number disappears, as shown in line 2 . Based on this notification function, we can identify three types of participants in KakaoTalk interaction: 1) active participants, who write; 2) passive participants, who just read, not typing at all; and 3) the idle, or soon-to-be participants, who have not checked messages yet. The active participants can be both on the primary or the secondary floor while the passive participants are on the secondary floor and stay silent. In this study, only active participants, who write, will be discussed. 


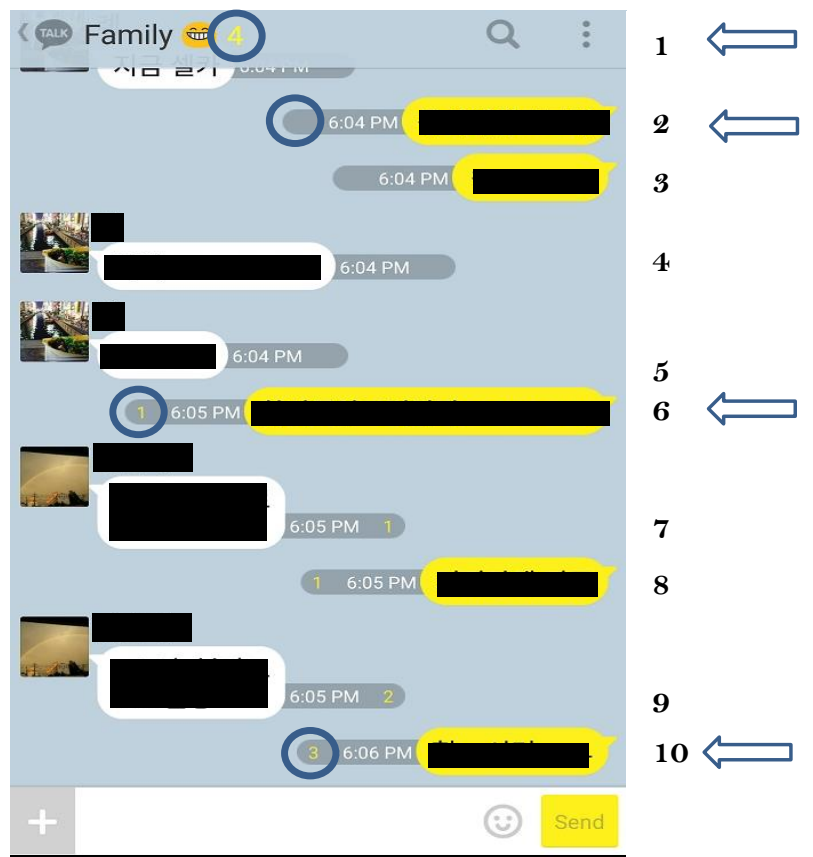

Figure 1 KakaoTalk Message-Read Notification

\section{CHAPTER 4 ReSEARCH MeTHODOLOGY}

\section{Data Collection}

The examples for this study are drawn from KakaoTalk group Instant Messages among five female Korean friends including me between August, 2013 and April, 2014. I adopted the data collection methodology from West and Trester (2013). As seen below, I created a private Facebook event page including the description of the research, invited the friends, and asked them to click the "going" button only if they agreed to allow me to download and use our prior KakaoTalk Instant Messages for the study. Thus, the "going" button indicates the place of informed consent. I set the end time of the event to April 22nd, 2015. By then, this research will have been completed. 


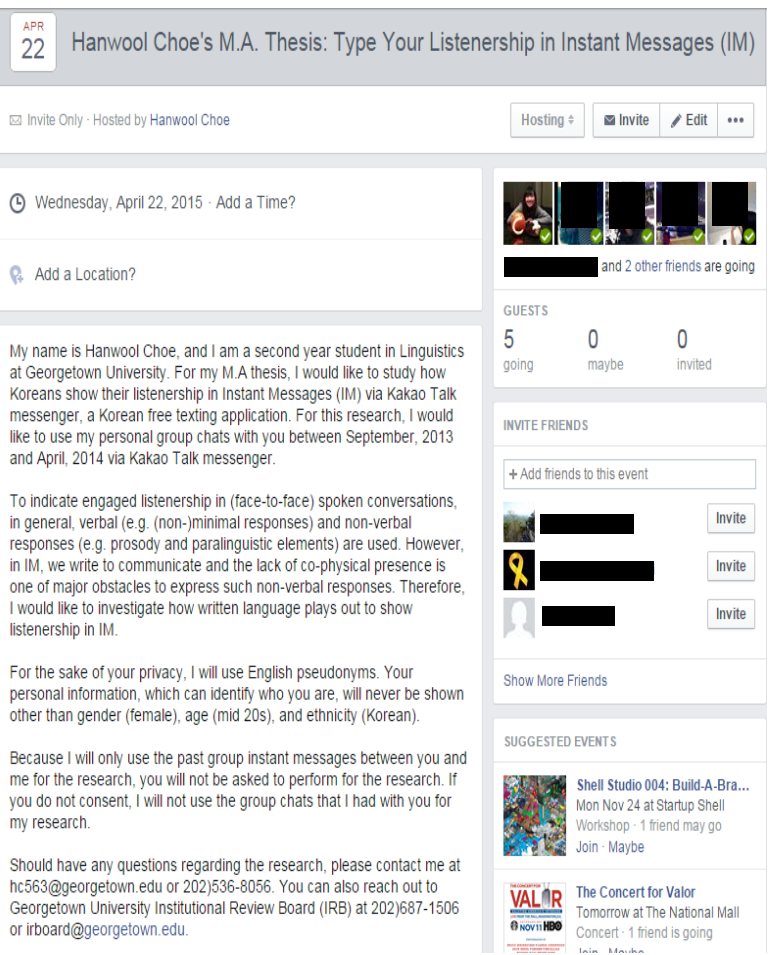

Figure 2 Data Consent via Facebook

\section{Profiles of Conversation Participants}

Any references to specific locations and participants' names except mine, which could reveal personally identifiable information, have been changed. There are five Korean females including me in a KakaoTalk group chat room. We are in our mid-twenties: Yuna, Dara, Mina, and I are twenty seven years old and Suji is one year younger. Yuna, Dara, Mina, and I are from Seoul, the capital of South Korea, and Suji is from Daegu, the principal city of North Gyeongsang Province in eastern South Korea. Suji usually speaks a Gyeongsang dialect but she uses standard spoken and written Korean when she talks to the rest of us. We have known each other since August, 2012 as recipients of graduate school study fellowships. All of us came to the United States to study at graduate schools at about the same time. Suji and Mina go to 
same school but the others go to different schools in different cities in different states, so KakaoTalk is our major means of communication. To validate my interpretation of the data, I conducted online “playback," termed by Labov and Fanshel (1977), to elicit participants' comments upon looking at the conversation they participated in, by sending snapshots of particular excerpts to them and asking about the intentions underlying their messages at that time.

\section{Data Presentation}

Data will be presented in two columns to visually represent a series of Instant Messages. As seen below, I number each message with its time sent and its sender. The targeted participants for this study, or primary listeners will appear on the right column regardless of which floor they get. Each message is displayed in three ways; 1) original lines as typed in Korean, 2) word-by-word English translation in italics, and 3) idiomatic English translation. If the original lines consist of words, not sentences, there will be only an idiomatic English translation. Regarding nonverbal messages such as Korean letters as pictograms, I neither translate them into English nor provide the English equivalents in order to keep the sense of what they look like and what they semantically represent in the original, explaining their meaning, if necessary. The targeted lines for analysis are in bold.

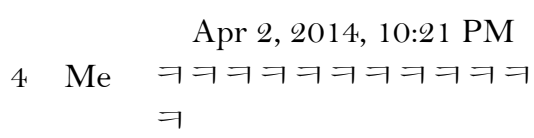

Apr 2, 2014, 10:21 PM

윤다라

YoonDara

Dara Yoon
Mina 5 
Along with the aforementioned introductory information, what follows now presents data analysis, which gives the examples of minimal responses, machine gun listenership, and framing phenomena.

\section{ChaPTER 5 Listenership In Digital Discourse}

\section{Minimal Responses}

Minimal responses are the most representative indication of listenership. Fellegy (1995:186) defines minimal responses as utterances such as mmhmm, yeah, uh-huh, and right, used by a listener during a speech event to signal a certain level of engagement with a speaker. If this level of engagement with a speaker is high, minimal responses can signal active listening (Schegloff 1972), but listeners can use minimal responses when bored too (Bublitz 1988). Gardner (2002) notes that minimal responses guide the speaker and provide feedback during

the course of talk, for example, whether listeners “... approve of, agree with, disagree with, will remain silent on, or will have something to say about the prior talk" (3). Gender differences are also pronounced in minimal response; Fishman (1978), for example, taped a couple's conversation and found the man used the minimal response to show he agreed, whereas the woman inserted the minimal response between the man's utterances throughout the talk as support work. As a result, the woman perceived the man's fewer minimal responses to display lack of interest and to attempt to discourage interaction.

The next three excerpts will provide three different examples of Korean minimal responses based on age. Excerpt 1 presents a simplified minimal response, 0 , between participants of the same age and also represents how Koreans shorten the minimal response to 
make it easier and faster to talk in digital conversations. Excerpt 2 presents an informal minimal response, 응 /eung/, by older participants. The first two minimal responses are translated as yeah in colloquial English. Excerpt 3 presents an honorific minimal response, 네 /ne/, by a younger participant, translated as yes in English. The findings are that the first two minimal responses are used as support work to encourage the ongoing talk and the last minimal response is used as support work to give evidence of the speaker's understanding.

\subsection{Simplified Minimal Response between Participants of the Same Age}

Crystal (2008) says that people tend to abbreviate words to speed up communication in text messaging. For the same reason, as mentioned earlier, Koreans, among close and informal groups of people, use a simplified minimal response in digital conversations, which is the consonant, ㅇ [ieung], taken from the informal minimal response, 응 /eung/. The simplified minimal response, $O$, is much more informal than 응 /eung/. Although Koreans commonly use this minimal response in pairs like $\bigcirc \circ$, they type it as many times as they want such as $\bigcirc \circ \circ \circ \circ \bigcirc$. The more $\bigcirc$ [ieung] is typed, the more it emphasizes that listeners understand what is being said or encourage the current talk.

\section{$\leq<$ Excerpt $1>>$}

Right before the following conversation, I was explaining to Dara about why I did not study at the library. At the time I felt very uncomfortable with the library's furniture because the desk was too low for me, which caused me to bend over more than usual to study. As a response, Dara starts to talk about her troublesome chair, which she has recently replaced with a new chair. While she starts talking on the primary floor as a response to my talk, I move 
down to the secondary floor and show active listenership through the repetition of the simplified minimal response. Dara and I show mutual listenership toward each other.

Feb 8, 2014, 11:44 PM 한울아 나는 이상한게

$1 \quad$ Dara Hanwool-a(informal name suffix) I-neun(subj. marker) strange

Hanwool, you know what

Feb 8, 2014, 11:44 PM 지금 기숙사방에 잇는 의자가 높은건 아닌데 책상이 낮아서

Now dorm room at

3

Dara

exist chair-ga(subj. marker) high not deski(subj. marker) low I don't think my chair is particularly high, but my desk seems too low for me

Feb 8, 2014, 11:44 PM 나도 그게 너무

$5 \quad$ Dara

불편햇거든

I-also that too uncomfortable

This bugs me so much

Feb 8, 2014, 11:44 PM 그래서 나는 의자를 삿어 20 불 주고 So I-neun (subj.

7 Dara marker) chair-reul (obj. marker) bought 20 $\$$ paid

So I bought this chair for 20 bucks
Feb 8, 2014, 11:44 PM

O 0

Me 2

yeah yeah

Feb 8, 2014, 11:44 PM

$\circ 0$

Me 4 yeah yeah

Feb 8, 2014, 11:44 PM

00

Me 6

yeah yeah 
Feb 8, 2014, 11:44 PM

$$
8
$$

Dara

$$
\begin{aligned}
& \text { 너무 편해 } \\
& \text { It's so comfortable }
\end{aligned}
$$

Feb 8, 2014, 11:45 PM

9 Dara

Feb 8, 2014, 11:45 PM

지금 저거야

10 Dara Now that

That's the chair I bought

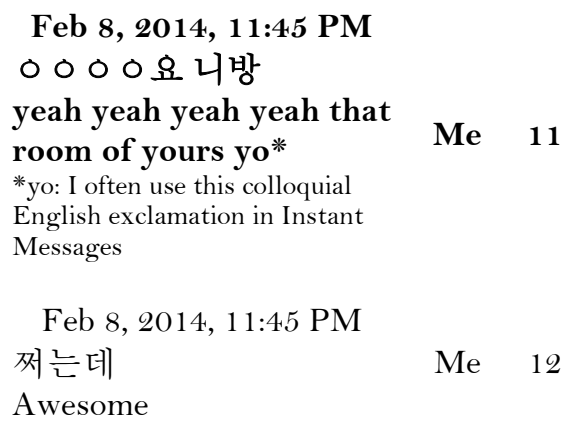

The simplified minimal response, written ten times by me throughout the conversation, expresses my interest in the topic of her talk. My active listenership originates with my chair talk in the previous conversation, which lets Dara get on the primary floor to share her chair issue with me as a response to my talk. Her detailed narrative represent her eager involvement with my talk; she describes her own chair in line 3, "I don't think my chair is particularly high, but my desk seems too low for me," moves onto her uncomfortable feelings in line 5, "this bugs me so much," and then visually shows how to solve the problem by sending a photo of her newly bought chair in line 9. I, in turn, show active listenership toward her talk in the form of the simplified minimal response to encourage her to keep talking such as “ $\bigcirc \quad$ [yeah yeah]” in lines 2,4 , and 6 . Interestingly, I respond to every single message she has sent me by using the simplified minimal response in pairs, which appears to put a rhythmical beat between her 
messages. But, she typed so quickly from line 7, "So I bought this chair for 20 bucks" to line 10, "That's the chair I bought," that I had no chance to respond. Thus, I make up for that in line 11, “ ○ ○ $\bigcirc$ [yeah yeah yeah yeah]."

In this conversation, Dara and I mutually trigger each other's listenership; one is narrative listenership, done by Dara on the primary floor, to respond my talk and the other is simplified minimal response listenership, done by me on the secondary floor, to respond to her narrative. This quick and convenient simplified minimal response goes along with her fast talking pace and demonstrates a high level of solidarity between Dara and me, who are the same age.

\subsection{Informal Minimal Response by Older Participants}

The following conversation presents the informal minimal response, 응 /eung/, used by older participants, Dara and me, to a younger participant, Suji. Readers can notice that Suji is younger than Dara and I, based on her language choice such as 언니 / eonni/, which is a respectful address term that females use to call their older female friends and sisters. Dara and I use various forms of the minimal response and repeat them in pairs as a sign of support and active listenership.

\section{$\leq<$ Excerpt 2 $>>$}

Suji wants to use her first summer as a Ph.D. student effectively, so she decides to start writing a qualifying paper earlier than planned and doing an independent study.

Jan 27, 2014, 6:45 PM 언니 나 여름방학 동안 1 Suji 페이퍼에 올인할건데 Eonni I summer vacationduring paper-at all in-and 
Eonni, I am going to invest my summer in writing papers

Jan 27, 2014, 6:45 PM

나 6 월부터 8 월까지

두달 반 넘게 시카고

있거든요

I June-from August-to two

4 Suji months half over Chicago will be-yo (polite suffix)

I am going to be in

Chicago from June to

August, more than two and a half months

Jan 27, 2014, 6:45 PM

5

Suji

암껏도 안하고

Nothing doing

Doing nothing

Jan 27, 2014, 6:45 PM

그래서 그냥 퀄페이퍼

미리 써놓고 연구나

할려고

So just qualifying paper

8 Suji beforehand write research do and

So I am just going to start writing my qualifying papers earlier and researching
Jan 27, 2014, 6:45 PM

응응!!

Me 2

Yeah yeah!!

Jan 27, 2014, 6:45 PM

오오

Dara 3

Yeah yeah!!

Jan 27, 2014, 6:45 PM

옹옹

Me 6

Yeah yeah

Jan 27, 2014, 6:45 PM

웅웅

Dara 7

Yeah yeah

Jan 27, 2014, 6:45 PM

오오

Me 9

Yeah yeah

Jan 27, 2014, 6:45 PM

좋은데

Me 10 
Dara and I type 응 /eung/ in various ways and repeat them in pairs: first, we respond to Suji’s message by saying, “응응 / eung eung/" in line 2. Then, we change it to 오/oh/, consisting of $\bigcirc(\mathrm{C})$ and $\perp(\mathrm{V})$, and reiterate it like "오오 /o o/," in line 3 and line 9. We also transform 응 /eung/ to 옹 /ong/, consisting of $\bigcirc(\mathrm{C}), \perp(\mathrm{V})$, and $\bigcirc(\mathrm{C})$ and repeat it twice like “옹옹 /ong ong/," in line 6, and this time, we answer Suji's messages by using 웅 /ung/, consisting of $O(\mathrm{C}), \mathrm{T}(\mathrm{V})$, and $\mathrm{O}(\mathrm{C})$, and repeating it like “웅웅 /ung ung/ in line 7." This joint listenership activity by Dara and me is inserted between Sujis messages throughout the talk. Their similar pronunciation and appearance, made of the consonant, $\bigcirc$ [ieung], create rhythms between Suji's messages, which similarly happens in excerpt 1.

Similar to my listenership from excerpt 1, my and Dara's listenership through repetition functions as encouragement to keep Suji talking about her summer plans. When Dara and Suji were asked via KakaoTalk to tell me about how they felt at the time, Suji said that while talking, she had the sense that her talk was well received by Dara and me. Thus, Suji, the speaker, felt our support work through the minimal responses we used. Dara's comments about the conversation were especially interesting. She said, "I felt like I had to repeat 옹옹 /ong ong/, for example, twice, which was a gesture to signal that I was into the conversation; so the minimal response here implies like 옹옹 (so what is next tell me)." In other words, Dara does not consider the minimal response as s simple response but as a propeller to move the talk forward.

To sum up, excerpts 1 and 2 demonstrate that minimal responses through repetition in pairs as well as repetition throughout the talk, function as support work. Additionally, this 
excerpt 2 shows that variation of the form of the minimal response is another key listenership ingredient to exhibit active listenership.

Now, I turn to the honorific minimal response, 네 /ne/, used by a younger participant. This type of minimal response is also used as support work, but the purpose of support work is to signal agreement with a speaker's understanding.

\subsection{Honorific Minimal Response by a Younger Participant}

Honorifics are linguistic forms that constitute formal and polite use of language. In Korea, age is a factor that determines register. Younger people must use the honorific minimal response, 네 /ne/, consisting of $ᄂ(\mathrm{C})$ and 게 (V), to older people even if they are friends. Younger people could use the informal minimal response or the simplified minimal response if older friends allow their younger friends to talk in a casual (informal) way, or if their level of solidarity with older people is high enough, as with family, siblings, and close friends of the same age. However, even if the younger friends do not have to use such respectful language to their older friends, siblings, or close family members, they still must use honorific forms of address such as 언니/eonni/, as seen in excerpt 2.

\section{$\leq<$ Excerpt $3>>$}

Previously, Mina and Suji were talking about the distribution of their grants. Our grants are sent to us five times a year, which includes monthly stipends. Mina was confused by the calculation, so she was asking Suji about what portion of the grant constitutes the monthly stipend. Suji tells her the whole amount of stipends we receive throughout the year and then Mina begins to type what she has understood so far, based on Suji's explanation. Suji uses the 
honorific minimal response, 네 /ne/, in pairs to signal her agreement with Mina's understanding.

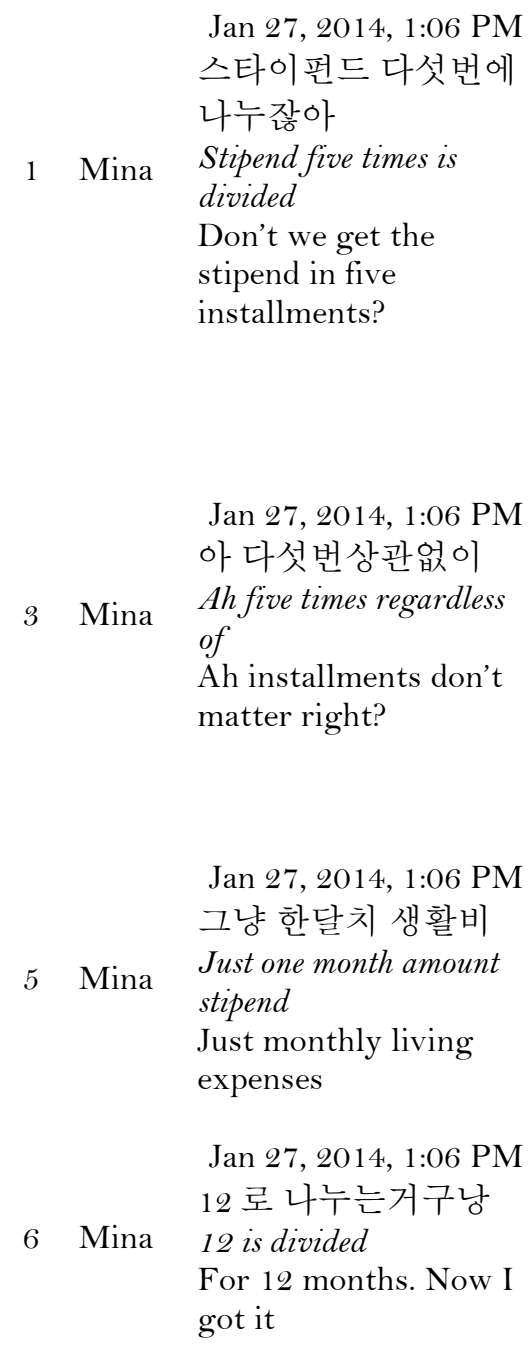

Jan 27, 2014, 1:06 PM 13000 불 $13000 \$$

$\$ 13000$

Suji $\quad 2$

Jan 27, 2014, 1:06 PM

네네

Yes yes

Suji 4

Jan 27, 2014, 1:06 PM 그냥 한달치 생활비

Just one month amount stipend

Just monthly living

Jan 27, 2014, 1:06 PM

12 is divided

got it

Jan 27, 2014, 1:06 PM

네네 언니는 학비

안받으니까 그냥 12 로

나누면 될 듯!

Yes yes eonni-neun

(subj. marker) tuition

fees not-receive-

because just 12 is

divided by looks like!

Yes yes since eonni gets no tuition, dividing it 


\section{by 12 seems right!}

Suji uses a pair of minimal responses, 네네 /ne ne/, in lines 4 and 7 . Her use of this honorific minimal response suggests two things. First, her response signals her level of solidarity with Mina as well as the age-oriented hierarchy between them. Due to the age difference, she is not free, as Dara, Mina, and I are, to use the (simplified) informal minimal responses, which are shown in the previous excerpts. If she had established a higher degree of intimacy with Mina, she might use informal responses and modify the responses like Dara and I did in excerpt 1 and excerpt 2 . However, by interviewing her, I found that her repetition of 네 /ne/ is her way to show closeness and positiveness to older friends. I very occasionally see people reiterate 네/ne/ twice like 네네/ne ne/, but I have the intuition that she quite often does it in our conversations. According to her, she often uses a pair of 네네 / ne ne/ to her closer older friends, which is, I argue, her alternative way to show solidarity to older people. Second, the function of her minimal response is different from the previous excerpts. After Suji’s message in line 2 , “\$13,000,” Mina’s messages do not seem to be oriented to Suji. It would rather appear as if she is writing down her own process of understanding the distribution of monthly stipends. Nevertheless, Suji continues writing the honorific minimal responses to accompany Mina’s understanding. As seen in line 7, "Yes yes since eonni gets no tuition, dividing it by 12 seems right!" her minimal responses are interpreted as a signal that "you are on the right track of how to calculate monthly stipends." This type of support work provides feedback in the form of confirmation while listeners show encouragement as support work in excerpts 1 and 2 . 
The three types of minimal responses used in the above excerpts demonstrate how minimal responses are adjusted to the medium, EMC, the level of solidarity, and the age hierarchy among friends. The excerpts also illustrate two kinds of listeners' support work encouragement and feedback. The patterns also support Tannen's (2007) discussion about repetition as an indicator of engaged listenership.

Next, I will look at what I call machine gun listenership. This type of listenership exhibits a listener's interest and engagement in talk. It is characterized by the fast pace of asking and answering without hesitation or pause.

\section{Machine Gun Listenership}

Tannen (2005) introduces the notion of conversational style. According to her, "style is not something extra or frivolous, added on like frosting on a cake. It is the stuff of which the cake is made" (14). A person's utterances convey her or his meanings through her or his own conversational style; conversational style shapes the way meaning is encoded in and derived

from speech, according to Tannen. She identifies two conversational styles in interaction: highinvolvement and high-considerateness, and examines many dimensions of conversational mechanisms among friends in spoken interaction: 1) whether participants prefer personal or impersonal topics, 2) how they use paralinguistic features and speech prosody, 3) how enthusiasm is exhibited through questions, responses, repetition, etc., 4) whether participants are tolerant towards noise or silence, 5) whether they overlap or not, 6) when and how much participants laugh, and 7) how pacing is managed. Those who have high-involvement styles ask fast-paced questions, talk at a fast pace with high amplitude, overlap, exhibit enthusiasm, and prefer personal topics, whereas those who have high-considerateness styles allow longer pauses, hesitate, use moderated paralinguistic effects, and prefer impersonal topics. 
Among the many features of conversational styles she describes, Tannen pays special attention to machine gun questions. She presents machine gun questions as a high-involvement strategy involving high pitch, reduced syntactic form, fast rate of speech, and directness of content, intensified by a fast pace and occurring with much overlap and little pause between utterances. She compares the strategy of rapid questions to machine-gun fire and interprets it as a signal showing solidarity, enthusiasm, and interest in others' talk. Later, Tannen (2013) applies the notion of conversational styles to written digital discourse. She notes that females tend to use multiple exclamation points (e.g., "I miss you too!!!!!!!”) and question marks (e.g., "R you going to Justin and Lance's tonight??”) as expected enthusiasm markers - "unmarked in the linguistic sense" (106) in instant messaging. In one of the examples she provides, when a younger brother sends instant messages to his sister, who has proposed to visit him, without any of these markers, she thinks that he is not enthusiastic about her visit. He insists he is, and she believes him. Therefore, in written digital discourse, the ways people express their enthusiasm are different and thus can be misunderstood.

Building on Tannen's (2013) observation of conversational styles in digital discourse and extending Tannen’s (2005) notion of machine gun questions, I note that a machine gun-like conversational style can also be used in written discourse and can appear in the form of answers as well as questions. In the following examples, I identify two distinct forms of machine gun listenership: machine gun questions and machine gun answers. These two machine gun listenership strategies indicate my enthusiasm for talk as a primary listener on the secondary floor by asking and answering in a machine gun fashion. My machine gun listenership enriches the speakers' utterances rhythmically; in the machine gun questions listenership, I fire a series of quick questions without pause between utterances. In the machine gun answers listenership, 
I fire a series of rapid answers to one message. These two types of machine gun listenership demonstrate a high-involvement listenership strategy in Instant Messages, which exhibits both humor and solidarity.

\subsection{Machine Gun Questions}

Dara went back to South Korea during her spring vacation (excerpt 6) for a medical check-up including dental treatment, which is too costly in the United States. In the conversation prior to the following excerpt, we were talking about when to buy airline tickets to Korea for the summer and Yuna tells us that she bought a round-trip ticket only for $\$ 1,000$. Suji and I are in awe of Yuna's finding such a good deal and of Dara's visiting Korea. In the following conversation, Dara starts to talk about how she is doing in Korea, and I ask her a series of questions about Korea in the form of machine gun listenership.

\section{$\leq<$ Excerpt $4>>$}

$$
\begin{aligned}
& \text { Mar 25, 2014, 8:39 PM } \\
& \text { 지금 막상 한국오니깨... } \\
& \text { 내가 언제 미국갓엇나...? } \\
& \text { ㅋㅋㅋㅋ하는생각 } \\
& \text { ㅋㅋㅋㅋㅡ } \\
& \text { 1. Dara } \text { Now Korea came... I-ga (subj. } \\
& \text { marker) when United States } \\
& \text { went...? } \text { By the way, now that I am } \\
& \text { in Korea... I am thinking } \\
& \text { like was I ever in the } \\
& \text { States...? }
\end{aligned}
$$

Mar 25, 2014, 8:39 PM

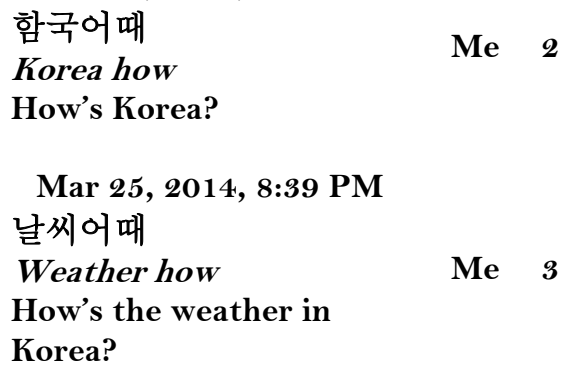


Mar 25, 2014, 8:39 PM 응 맞아 그 그게 좀 달라서 싸지는득

4. Yuna Yeah right that a little bit different get cheap Yeah right $\exists$ I think the difference makes it cheaper

Mar 25, 2014, 8:40 PM 날씨너무 좋아

6 Dara Weather so good

The weather is unbelievable

Mar 25, 2014, 8:40 PM ヨココココココココココ ヨココココココココココ ヨコココココココココ 다라 언니 그냥 계속 있던 집 같아요?

Dara eonni just continue

8 staying home look like?

ヨココココココココココ ヨココココココココココ ヨコココココココココ Dara eonni, does it feel strange or do you feel like you were there since forever?

Mar 25, 2014, 8:40 PM ㅋㅋ크사랑니 뽑는게 트랜드야

10 Dara A wisdom tooth pull out trend

ヨコココ Pulling out a wisdom tooth is the trend
Mar 25, 2014, 8:40 PM 거리는 많이 달라졌니 Streets a lot changed How are the streets in Korea?

Mar 25, 2014, 8:40 PM 공기는 어때 Air how

Me 7
Me 5
Mar 25, 2014, 8:40 PM

요즘 트렌드는 뭐야

Current trend-neun (subj. marker) what

What's the current trend in Korea? 
In this excerpt, I repeatedly fire questions as Dara talks about her stay in Korea. My machine gun listenership starts from line 2, "How's Korea?” and then without hesitation, it is followed by the next question in line 3, "How's the weather in Korea?" Although my questions are not answered yet, I do not wait and continue my machine gun listenership in line 5, "How are the streets in Korea?” After I write a rapid series of three questions, Dara finally responds to me in line 6 , "The weather is unbelievable," which is a response to one of my questions line 3 , “How's the weather in Korea?” Instead of waiting for her to answer the rest, my machine gun continues in line 7, "How's the air in Korea?" and in line 9, "What's the current trend in Korea?." She responds to me again in line 10, "pulling out a wisdom tooth is the trend," which is her joke-like answer to only one of my questions. I played back this exchange with Dara to ask why she did not answer all my questions. She remembered that since many messages came up simultaneously, she answered the only questions which caught her eyes. Her comments demonstrate that my pace of asking was faster than her pace of reading and answering my messages. I suggest that machine gun listenership in the form of questions was a highinvolvement listenership strategy to show my enthusiasm for her talk. The topics from my quintuplet questions about Korea - Korea, the weather, the air, the streets, and the current trend - are not what I literally wanted to know about. They symbolically represent homesickness for Korea, which I had not visited for a while and missed a lot.

\subsection{Machine Gun Answers}

The next excerpt illustrates machine gun listenership appearing in the form of multiple answers to an utterance. This type of machine gun listenership also represents a listener's enthusiasm for a speaker just like machine gun questions listenership in the previous excerpt. In the following example, Mina sends the message that she is craving hot food, which is 
understood as a topic suggestion from the primary floor. I respond to her message by sending a series of rapid answers about hot food.

\section{$\leq<$ Excerpt $5>>$}

Feb 28, 2014, 5:00 PM 아 문가뜨끈한거먹고싶다

1 Mina Ah something hot eatwant

I want something warm and filling

Feb 28, 2014, 5:04 PM

7 Mina 사켘コㅋ

Sake
Feb 28, 2014, 5:04 PM 홍합팅

Me 2

Mussel Soup

Feb 28, 2014, 5:04 PM

우동

Udon

Me 3

Feb 28, 2014, 5:04 PM 오뎅탕

$\mathrm{Me} \quad 4$

Fishcake soup

Feb 28, 2014, 5:04 PM

사케

Sake*

*Sake is a type of Japanese drink, which people usually warm up before drinking.

Feb 28, 2014, 5:04 PM 갑자기 본죽 먹고싶네

Suddenly Bon Porridge eat-want

I am craving rice porridge from Bon Juk* in Korea

*Bon Juk is the name of Korea's franchised porridge restaurant. Koreans eat rice porridge as comfort food when it is cold or they are sick.

Feb 28, 2014, 5:04 PM 참치야채죽 맛있눙데
Me 6

Me 5

Me 6




$$
\begin{array}{cll} 
& & \multicolumn{1}{c}{\text { Feb 28, 2014, 5:04 PM }} \\
9 & \text { Mina } & \text { 난호박죽... } \\
& \text { I pumpkin porridge... } \\
& \text { I love pumpkin porridge... }
\end{array}
$$

\author{
장저림이랑 \\ Tuna veggie porridge \\ delicious Jangjorim-with \\ I love the porridge with \\ canned tuna and \\ vegetables, and \\ Jangjorim* \\ *Jangjorim is a Korean side dish \\ made of braised beef and eggs.
}

Feb 28, 2014, 5:05 PM

헐 호박죽에 들어있는

떡같은거

Oh my god pumpkin porridge-at include rice cake-something-like

Oh my god I am dying

for those little rice balls

in pumpkin porridge

Mina’s message in line 1, “Ah I want something warm and filling,” has been unanswered for four minutes as seen in my first message in line 2, "Mussel soup.” After those four minutes, I rapidly send her a series of hot foods that I want to eat: Mussel soup in line 2, Udon in line 3, Fishcake in line 4, Sake in line 5, and Bon Porridge in line 6. My answering is a type of machine gun listenership because the list is in response to one message and occurs without hesitation between messages and with fast pace, creating written-rhythms in my listenership. Possibly, my machine gun answers listenership may be intended to compensate for my delayed response to Mina. However, based on my recollection of the conversation, her message stimulated my desire for hot food. Then, my hot food desire occurs in greater detail by listing specific foods and sometimes giving comments as in line 8, "I love the porridge with canned tuna and vegetables, and Jangjorim," and in line 10, "Oh my god I am dying for those little rice balls in pumpkin porridge.” Mina commented later that my series of messages had prompted her to visualize particular foods in her head, which was vague when she first sent the message in line 1, 
"Ah I want something warm and filling." Therefore, my machine gun answers listenership not only signals my high-involvement with the speaker but also specifies her hot food wishes too, which can be called mutual involvement about the topic between Mina and me.

In the next section, I show how listeners achieve their listenership by use of framing phenomena, and what alternative contextualization cues they use in Instant Messages to do so.

\subsection{Framing Listenership}

Bateson (1972) first conceptualizes framing through the observation of monkeys playing at a zoo. He notes that their seemingly combative action does not "denote what those actions for which they stand would denote” (185). Borrowing Bateson's notion of framing, Goffman (1974), exploring human interaction, defines frames as "definitions of a situation" (10) and discusses the nature of frames: lamination. As we create and participate in frames through individual utterances and activities, we also construct our own footings (Goffman 1981), or alignments, which "we take up to ourselves and the others present as expressed in the way we manage the production or reception of an utterance" (128).

Frames change and footings come along with them; as Goffman writes that "a change in our footing is another way of talking about a change in our frame for events" (128). As one way to understand the complexity of framing, understanding what Gumperz (1977) called contextualization cues is crucial. According to Couper-Kuhlen (2001:16), contextualization cues "function by indexing or evoking interpretive schemas or frames within which inferential understanding can be achieved." However, frames are not all about contextualization cues but are "more complex" (Tannen and Wallat 1987:401). We also need to know how the web of laminated, or layered, frames is woven because frames do not simply change to others; they are laminated to one another like a crepe cake layered with multiple crepes. Gordon (2008, 2009) 
examines different ways to accomplish framing phenomena: 1) "frames are overlapped where an utterance is situated in (at least) two frames at once" (2009:1 16); 2) "a frame with a more specific metamessage is completely embedded in a frame with a more general metamessage" (2009:141); 3) frames are reframed in sequence; and, 4) multiple frames are blended, happening simultaneously. In this study, I focus on reframing and alignments.

Tannen and Wallat (1987) is one of the most significant framing studies to explore the intricate nature of framing. They develop theories of framing through the examination of a videotaped interaction among a pediatrician, a child, and the child's mother. Defining "interactive frames" as "a definition of what is going on" (206), Tannen and Wallat demonstrate that there are three major frames the doctor engages with: "the social encounter; examination of the child and a related outer frame of videotaping; and consultation with the mother" (210) and that there are three different registers the doctor uses to deal with each audience: teasing register for the child, conversational register for the mother, and reporting register for the non-present pediatric residents. When the doctor examines the child's stomach, for instance, she uses an exaggerated intonation and pitch to tease the child and further comfort her to make the examination go smoothly, for example, by saying "Is there peanut butter and jelly in there?." When she reports her diagnostic findings to the pediatric residents, she uses a flat tone of voice with medical terms, being aware that the video recorder will be used for training them. Her skillful frames management, by switching from one to another including register shifts, reflects the complexity of the doctor's task.

In a different study, Tannen (2006) explores frame shifting phenomena, including the notion of reframing. She defines reframing as "a change in what the discussion is about" (601), and illustrates it in an argument that took place between a couple: Neil and Clara, about a 
cardboard box, which Clara asked Neil to take to the post office. The argument about the box is later reframed as an argument about Neil's emotional support for Clara. Tannen also notes that reframing can be accompanied by rekeying, "a change in the tone or tenor of an interaction” (601): “a rekeying occurs when the speakers' tone of voice, amplitude, lexical emphasis, rhythm, intonational contours, or other qualities of speech indicate a change of emotional stance" (601). Thus, the argument between the couple is rekeyed later when it is treated with laughter and humor. Drawing on Tannen's concept of reframing, Gordon (2008) highlights the sequential transformation of reframing through an example where a mother reframes a conflict with her daughter as playful, by introducing a spelling test, during dinner preparation time.

Frames are usually understood and defined by ongoing activities in interaction. I note that speaking and listening are also activities that can make contributions to framing as well. To be specific, in Tannen and Wallat (1987), when the doctor is answering the mother's questions, their interaction is framed as "consulting." In other words, what discursively constructs this consulting frame is ongoing speaking and listening between the mother and the doctor, or discursive activities; throughout their discursive activities, the situation can be produced and finally defined as "consulting." It means that every interactional frame includes discursive activities performed by all participants, which I call discursive frames. These discursive frames, a lower level of frames - what is discursively going on - validate and contribute to an upper level of frame, or Frame.

Keeping in line with the discussion of framing, I now turn to my data to see how listeners manage framing phenomena to show their listenership. In the first example, Suji, as a primary listener, reframes the conversation repeatedly and takes a more active alignment with 
Dara, as the conversation proceeds. Re-reframing shows the progression of Sujis empathic understanding of a speaker's complaints and consequently rekeys the conversation as funny. This example also includes how rekeying operates in a non-phonological way. In the second example, I describe how a listener uses parentheses to visually mark her discursive frame shift from listening to speaking, which is a topic shift on a global level. This example also suggests a discursive function of parentheses in interaction. In the third example, parentheses supplant voice quality and help a listener to re-align toward her previous message, which consequently elaborates her emotional stance - anxiety - toward the on-going situation. Last, in the fourth example, a listener uses an animated sticker to signal that her previous messages are not intended to be taken seriously and that rekeys the conversation as playful.

\subsubsection{Re-reframing}

Right before the following conversations, Dara was complaining about her school's graduation requirements. Due to her studies in art history and her specific research interests, East Asian art history, she has to learn German, French, and Chinese. Also, a creative writing class is required. Studying four different foreign languages including English at the same time is very demanding for her. Suji studies linguistics and one of her graduation requirements is also learning a foreign language. She decided to study Mongolian during the summer session. In the following conversation, three frames occur in sequence. The first one is introduced by Dara where she is complaining about her heavy burden of foreign language courses and Suji feels sorry for her. The second frame, reframed as playful by Suji, is where she brings her Mongolian plan into the conversation and their focus is changed to the unpopularity of Mongolian as a foreign language to study. Last, Suji reframes the situation as funny again, by introducing a playful activity - talking in Chinese (transcribed in Korean) conversation; this 
time, reframing is reinforced by co-participation in the Chinese play with Dara. The third frame also shows that Suji's language shift from Korean to Chinese (transcribed in Korean) is a nonphonological way to rekey. As the conversation proceeds, its tone increasingly diverges away from what it was before by re-reframing. I will introduce each frame separately.

\section{$\leq<$ Excerpt 6 $>>$}

In this excerpt, Suji and Mina respond on the secondary floor to Dara's complaints by writing a variety of verbal and non-verbal listenership as a gesture of sympathy. First, as soon as Mina hears about Dara's complaints, she writes her frustration with the repetition of the consonant, $\exists$, which represents her nervous laughter derived from the ridiculous situation which Dara suffers. Suji sympathizes with Dara in two ways: first, she writes nonverbal expressions such as a sigh sound, "Ha," and Korean-lettered crying eyes, $\pi \pi$. Then, she asks a question to confirm that Dara did not volunteer to take several language courses at the same time.

\author{
Feb 19, 2014, 8:10 PM \\ 내가 눈물이 막 \\ 난다니까?????????!!? \\ 1 Dara I-ga(subj. marker) tears-i \\ (subj. marker) just \\ flow?????????!!? \\ I'm literally crying right \\ now?????????!!? \\ Feb 19, 2014, 8:11 PM \\ 지금 막 머리에 중국어랑 \\ 영어랑 다 뒤죽박죽이여 \\ 2 Dara Nowjust head-at Chinese-and \\ English-and all mixed up \\ Chinese and English all are \\ mixed up in my head right now
}

3 Mina Feb 19, 2014, 8:11 PM 


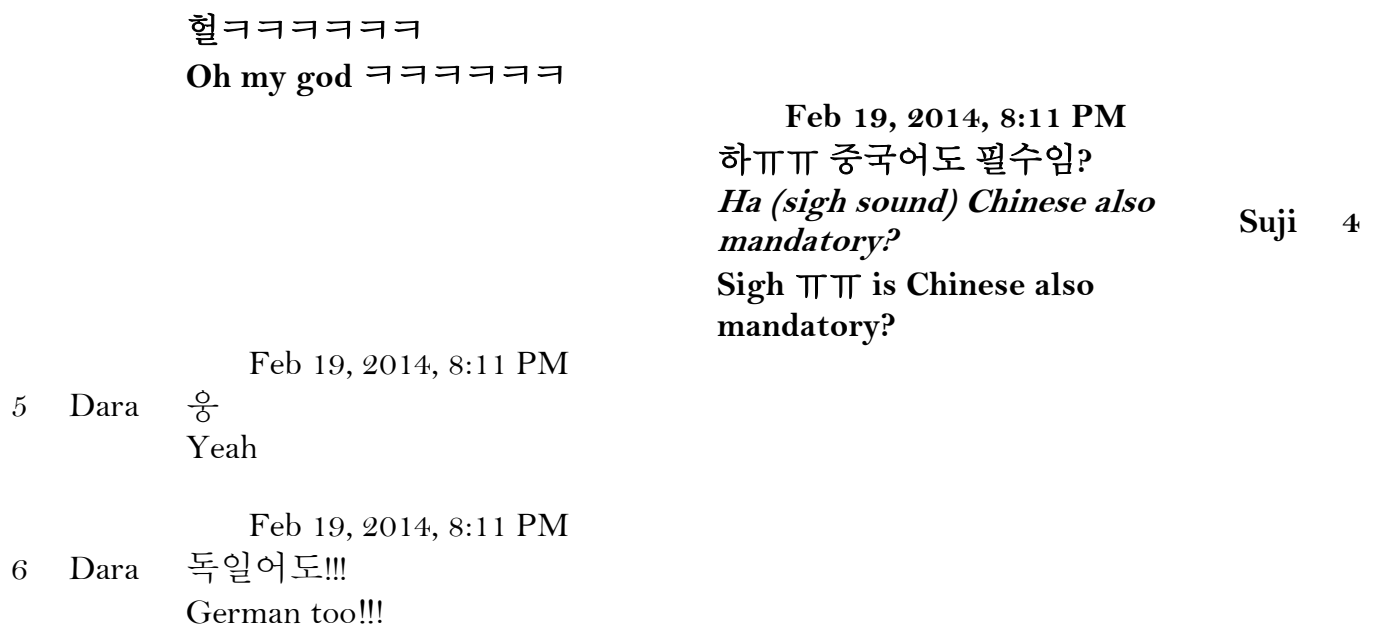

Dara emphasizes her emotional stance toward her heavy school workload in learning foreign languages by repeating question marks and exclamation points in line 1, "I'm literally crying right now?????????!??” Suji and Mina, who have co-membership with Dara as international students, understand well how awful it is and express their sympathy in a variety of expressions: nervous laughter in line 3, ヨコココココ, uttered by Mina, sigh, "Ha," crying eyes, $\pi \pi$, and a question in line 4, uttered by Suji. Suji later commented that since Dara has been already tied up with her major studies, she wanted to ensure that Dara did not voluntarily torture herself, by taking several language courses at the same time. It should be noted that her question comes from her concern rather than pure curiosity.

Throughout their sympathetic responses to Dara's complaints, Suji’s and Mina's listenership takes an alignment toward Dara to express their understanding of her harsh academic woes. Their listenership is central to contributing to this complaining frame.

\section{$\leq<$ Excerpt $7>>$}

In the following excerpt, Suji takes up a more active alignment with Dara, by getting the primary floor and saying that she will take a Mongolian class in the summer session - as a 
graduation requirement just like Dara’s. Instead of just sending sympathetic responses as in excerpt 6, now Suji actually brings in her situation and expands Dara's own situation to their co-situation, which consequently increases Suji's level of empathic understanding about Dara's situation. Excerpt 7 is part of the same troubles talk frame with excerpt 6: foreign language learning as a graduation requirement. But the following excerpt differs from excerpt 6 in that its focus is changed to Mongolian, a less commonly studied language, which unexpectedly creates humor in the context of the sympathetic communication about Dara's intense foreign language studying (excerpt 6). Since Suji’s plan to learn Mongolian could seem ridiculous due to the unpopularity of Mongolian in foreign language study, Dara laughs a lot. Dara's written laughing signals that the on-going conversation is reframed as playful.

Feb 19, 2014, 8:11 PM ヨコココココココココココ

8 Dara ヨコココココココココココ ヨコココココココココココ ヨココココ
Feb 19, 2014, 8:11 PM 언니난 계절학기에 몽골어 들어요

Eonni I summer session-at Suji 7 Mongolian listen Eonni, I am taking Mongolian for summer session
Feb 19, 2014, 8:11 PM 특수언어 하나 해야 졸업할 수 어가지고....ㅋㅋㅋㅋㅋㅋㅋㄱ Special language one-do graduate-can.... You know that I can only graduate if $I$ am able to speak one foreign
Suji 9 


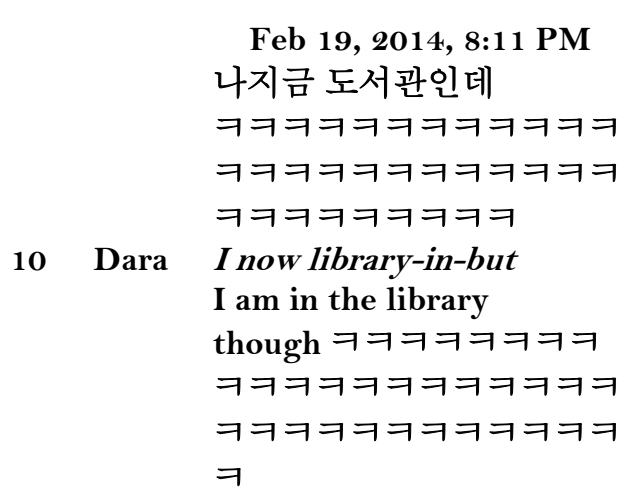

language.....ココココココ

나지금 도서관인데

ヨコココココココココココ

ヨコココココココココココ

though ヨコココココココ

フコココココココココココ

$\exists$

Feb 19, 2014, 8:11 PM

아프리카언어 할라다가

가까운나라 언어로 선택함

African language was going to

do closer countries language chose Suji 11

I was thinking about one of

the African languages, but

ended up with the language of

one of the neighbors of Korea

Here, Suji's listenership functions in two ways. First, it indicates that she emotionally becomes more involved with Dara’s situation. Line 9, “you know that I can only graduate if I am able to speak one foreign language," suggests that their co-membership is now more than international students as both share the same academic burden: being forced to learn foreign languages to graduate, which the rest of us do not have. Also, Suji's alignment toward Dara is shown in the form of sympathy in the previous excerpt, but in that Suji also shares a foreign language-learning requirement with Dara, they co-align with each other in the form of sharing the stressful issue. Second, Suji's decision to learn Mongolian starts to change the overall tone of the on-going conversation as playful. Dara's continuous laughing via the reiteration of the consonant, $\exists$, in lines 8 and 10 does not imply that she is ridiculing Suji’s learning Mongolian 
but it suggests that Suji’s language choice between African languages and Mongolian sounds surprising and somewhat funny.

Compared to the previous excerpt, we notice that Suji's listenership becomes more active and represents the progression of her empathetic understanding about Dara's academic stress by bringing in her own foreign language study situation. In doing so, her listenership gradually and unexpectedly reframes the conversation as playful, whereas it originally was sympathetic.

\section{$\leq<$ Excerpt 8 $>>$}

Now, Suji starts an improvised Chinese (transcribed in Korean) conversation right after Dara teases herself, by saying that her heavy Chinese workloads are making her feel as if she were a Chinese person. Suji uses the language shift as a means of rekeying in a nonphonological way and thus it reframes the conversation as playful one more time. Although the third frame has maintained the playful tone since the second frame, the origin of its playfulness comes from another activity - doing the Chinese play -, and more importantly, this Chinese play reframing is co-constructed with Dara whereas the Mongolian reframing is led by Suji.

During the Chinese play, Suji puts a tilde, $\sim$, at the end of her Chinese (transcribed in Korean) greeting: 니하오 /Nihao / [Hello ]; in Korean digital discourse, a tilde, , is usually added at the end of a sentence and used for lengthening the sound, which is similar to repeating letters in English digital discourse like “Thank you sooooooo much” or "Hiiiii.” Also, when Suji and Dara tell their full names in Chinese (transcribed in Korean), "Hwang" and "Yoon" refer to their family names respectively, which always come first before given names in Korean. 
Feb 19, 2014, 8:11 PM

나 이러다가 중국인

될수도 잇다 애들아

12

Dara

I eventually

I think I might become a

Chinese person, guys

Feb 19, 2014, 8:12 PM

$$
\text { ヨココココココココココ }
$$

14

Dara

ヨココココココココココ

ヨココココココココココ

ヨココココ

Feb 19, 2014, 8:12 PM

16 Dara

17 Dara
ㅋココココㅋㅋ오메나

ヨコココココココ Oh my god

Feb 19, 2014, 8:12 PM 워 쓰 잉 뒤오 뤼오

Wo Shi Yǐn Duō Luò

(Chinese: 我是尹多摞)

: I am Yoon Da Ra

I am Dara Yoon
Feb 19, 2014, 8:12 PM 니하오

Nihao (Chinese: 你好)

Hello

\section{$\begin{array}{ll}\text { Suji } & 1 \\ & 3\end{array}$}

Feb 19, 2014, 8:12 PM

워쓰 후왕씨우쯔!

WoShi HuangXiùZhì!

(Chinese: 我是黃秀智)

: Iam HwangSuJi!

I am Suji Hwang!
Suji $\quad 15$

In line 12, "I think I might become a Chinese person, guys," Dara continues complaining about her foreign language studies, teasing herself that her heavy Chinese schoolwork might make her Chinese. Note that Suji is the only active listener here to Dara even though she addresses everyone by saying "guys" in the same line. Suddenly, building on Dara' message, "I might become a Chinese person," Suji invokes the pretend play frame by writing a Chinese greeting in Chinese transcribed in Korean in line 13, "니하오 /Nihao / [Hello ]." When 
she continues writing in Chinese transcribed in Korean to tell her name in line 15, “워쓰후왕씨 우쯔! /Wo Shi HuangXiuZhiYing!/ [I am Suji Hwang!], I suggest that her continuous Chinese messages invite Dara to the pretend play frame. Finally, Dara accepts the invitation, and relays this impromptu Chinese conversation by telling her name in Chinese transcribed in Korean in line 17, “워 쓰 잉 뒤오 뤼오/Wo Shi Yin Duo Luo/ [I am Dara Yoon].” Through Dara's participation in the Chinese (transcribed in Korean) conversation frame, the conversation is successfully reframed as playful once again by Suji, whose tone is very different from the first excerpt where Dara expresses distress about her overwhelming foreign language courses. Also note that a rekeying occurs without any phonological phenomena: a language shift from Korean to Chinese (transcribed in Korean). This excerpt demonstrates that rekeying can be accomplished in writing.

As listenership toward Dara’s personal academic burden, Suji displays her sympathy, makes Dara's own situation their co-situation, initiates Chinese (transcribed in Korean) conversations, and consequently re-reframes the conversation, creating playfulness. In doing so, Suji, as a primary listener, reinforces her shared status with Dara. Her engaged listenership represents her active alignment toward the speaker, Dara, and is leading the conversation.

\subsubsection{Discursive Frame Shift Marker}

The next example shows how Yuna manages her discursive frame shift (from listening to speaking) and floor migration (from the secondary floor to the primary floor) through parentheses.

In the middle of the discussion about the quarter system where Yuna was participating as a listener on the secondary floor, sharing her experience and knowledge about it, Yuna tries 
to change the topic and get the primary floor as a speaker; it happens when I ask her a question. To manage her two different discursive frames on different floors, Yuna sends me a parenthesized message with the purpose of emphasizing her current discursive frame and floor. Her parenthesized message allows her to hold the primary floor and treats the previous topic including my question as secondary. I suggest that her strategic use of parentheses visually serves as her discursive frame shift marker.

I also propose that the excerpt reshapes the traditional usage of parentheses. Parentheses, ( ), are traditionally used to provide additional or ex tra information about the prior phrase or sentence. For example, parentheses in play scripts are often used to describe stage directions for spoken lines and the parentheses separate the directions from the lines that stage actors and actresses vocalize. Baron and Ling (2011) highlight "re-purposing of traditional punctuation usage” (62) in text messages among American undergraduates, particularly with regard to ellipses. But there is no work so far concerning the non-traditional usage of parentheses in EMC.

\section{$\leq<$ Excerpt 9 $>>$}

Right before the following conversation, Mina, Dara, and I were leading the discussion about which academic system is better, semesters or quarters. Since all of us are used to the semester calendar, the quarter calendar is very new to us. We ask questions to our primary listener, Yuna, who goes to school using the quarter calendar, to gain expertise in the quarter system, and she responds to our questions based on her experience. As the conversation proceeds, we are under the impression that the quarter system seems to be tougher due to its shorter breaks.

In the following excerpt, my question to a major listener, Yuna, is sent at the same time 
when Yuna changes a topic to get the primary floor to talk as a speaker. To manage

simultaneously occurring discursive activities: listening on the secondary floor and speaking on the primary floor, Yuna strategically uses parentheses.

\author{
Mar 25, 2014, 8:35 PM \\ 왜 서부는 \\ 쿼터제를하는거듸 \\ Why West Coast \\ 1 Me quarters-reul (obj. \\ marker) do \\ Why do they have the \\ quarter system in the \\ West?
}

Mar 25, 2014, 8:35 PM

응 $\pi \Pi$ 아 그리고 전에 말한

Yeah ah and before-at told Yuna 2

Yeah $\Pi \pi$ Ah about the

thing that I told you before

Mar 25, 2014, 8:36 PM

(모르겠어 Hanwool TाT)

(not-know Hanwool) Yuna 3

(I don't know

Hanwool TT)

Mar 25, 2014, 8:36 PM

돈 깎이는 거 나는 여름에

가는 건 안 깎인대 근데 그

스태프가 그랜티마다

다르다고

Money deduct I-neun (subj.

marker) summer-during go

not-deduct but the staff-ga Yuna 4

(subj. marker)

That deduction they make,

there will be no such thing

for me in the summer. One

of the staff told me that it is

different for each grantee

though

When Yuna is required to answer my question as a listener in line 1, "Why do they have the quarter system in the West?," she wants to change the topic and get the primary floor to 
become a speaker as seen in line 2 , “yeah $\pi \pi$ ah about the thing that I told you before." The minimal response, “yeah $\pi \pi$," with crying eyes is Yuna's late response to Mina’s prior message that "the quarter system sounds so harsh" from the previous conversation. And then, in the same line, she signals a topic shift - grants deduction during a summer break - as a means of taking the primary floor to be a speaker, which is what she really wants to do, by addressing a Korean discourse marker, Ah. According to Kim (2005), one of the functions that the Korean discourse marker, $A h$, has is to change a topic. To deal with her two discursive activities, she parenthesizes the message sent to me, which answers my question in line 3, "(I don't know Hanwool $\pi \pi$ )" and then in line 4, "That deduction they make ...," she gets into the details of "the thing I told you about before" from line 2. Throughout the parenthesized message, she signals again the end of the current on-going discussion and her listening activity and the beginning of the next topic and her speaking activity. Thus, parentheses used here graphically represent her discursive frame shift. If she parenthesized her message in line 4, "That deduction they make ..." instead, it would suggest that she was willing to stay on the secondary floor as a listener to keep the quarter system discussion as a primary topic, giving us quick information about the grants deduction she heard from her staff. Yuna later commented that by parenthesizing, she wanted to focus more on the grants deduction talk. It means that parenthesizing helps her to signal that she steps back off the listening frame and jumps into the speaking frame. This excerpt highlights speaking and listening as activities and uncovers the discursive function of parentheses in interaction.

I have demonstrated the ways in which listeners contribute to frame shifting through specific instances of re-reframing and discursive frame shift marker. I have also illustrated one 
possible way to rekey in written digital interaction: language shift and new discursive aspect of parentheses. The following two Instant Messages exchanges will show how a listener realigns herself toward her prior messages to elaborate her emotion and intention. The first example will highlight another discursive function of parentheses.

\subsection{Re-alignment Listenership}

In the following analyses, I zoom in the written ways in which a listener re-aligns herself toward her previous messages by rekeying them, through contextualization cues, which express her emotional stance and also leads the other participants to align toward her message in a way that she wants. I argue that the ways she rekeys here demonstrate alternative ways to overcome the absence of prosody and paralinguistic phenomena and thus reshape features of spoken language. The first example uses a parenthesized message as representing voice quality to lower the volume of her message and to show her anxiety about her class registration plan for next semester. The second example uses an animated sticker in which a little girl repeatedly slaps another little girl's face to rekey her previous messages as funny and to show she is teasing Dara.

\subsubsection{Re-alignment through Voice Quality $\leq<$ Excerpt 10 $>>$}

Suji and Mina go to the same school so they often talk about their school life in our chat room. When the time arrives for them to decide what classes to take for the next semester, Suji and Mina have not finalized their class schedules yet and this makes them stressed out. Mina tells Suji that she has been thinking of doing an independent study for next semester. But, to conduct the independent study, she has to contact a professor whom she has not met personally and it seems to worry her. 
Apr 2, 2014, 10:00 PM

아 담학기 뭐들을지

고민하느라 머리아파요

丁丁

1 Suji Ah next semester what to take

think because head hurts

Sigh thinking about what courses I am going to take for next semester hurts my head T丁

Apr 2, 2014, 10:00 PM

ㅋㅋㅋ크두과목에

인디펜던트 스터디?

4 Suji Two courses and independent study?

ヨココココ Two courses and one independent study?
Apr 2, 2014, 10:00 PM 나두TT 나는 인디펜던트 스터디할건데

Me too I-neun (subj. marker) Mina 2 independent study will do

Me too $T$ T I am going to do an independent study

Apr 2, 2014, 10:00 PM (혼자만 하기로 정함)

(alone do decide)

Mina 3

\author{
Apr 2, 2014, 10:00 PM \\ 모르는 교수한테 접근하는게 \\ 심리적 부담이.... \\ Not-know professor-to \\ approach psychological \\ burden... \\ This is so psychologically \\ stressful to contact a \\ professor for the first \\ time....
}

Mina’s message in line 5, “This is so psychologically stressful to contact a professor for the first time..." summarizes her emotional stance related to her own plan to do an independent study, which has not yet been approved by the professor whom she does not know and with whom she has to discuss it. Given that she does not know the professor's opinion about her idea 
and thus she is worried that her plan can be subject to change, she therefore does not want to "write" loud her tentative decision. That is why she writes as if she turned down the volume of her message so as not to make it public in line 3, "(It is my own decision)." Here, parentheses function as a vehicle for that kind of speech prosody. By parenthesizing, Mina signals her emotional alignment toward the class registration decision in line 2, "I am going to do an independent study," which is so provisional that she wants to keep it personal until after she talks to her professor. By doing so, she makes stronger her emotional stance behind the previous message in line 2, "I am going to do an independent study." Also, her way of lowering her voice is what we can observe in girls' talk where girls sit close to each other to chat and sometimes they cover their mouths to talk more personally. I suggest that her parentheses can be a written way to realize such a girls' talk style. I played back this conversation with Mina and her recollection of it was exactly the same as my interpretation: she lowered her voice because she had not made a final decision about it. She also told me that she often uses parentheses in her instant messaging. Also, note the content of the current discussion: what to take for next semester. Whether the onus of the decision to do the independent study lies with her or is shared with the professor is not a major topic; therefore, by parenthesizing, she treats the parenthesized message as secondary. To summarize, parentheses re-align Mina with her talk and serve to give additional information on her prior utterance.

\subsubsection{Re-alignment through Sticker Action}

Stickers are frequently used in instant messaging. KakaoTalk offers a variety of stickers, free and paid, featuring popular (cartoon) characters or celebrities to enrich text-based communication. Some of these stickers are included here. They are much stronger when it comes to conveying emotions visually and dramatizing written utterances. 


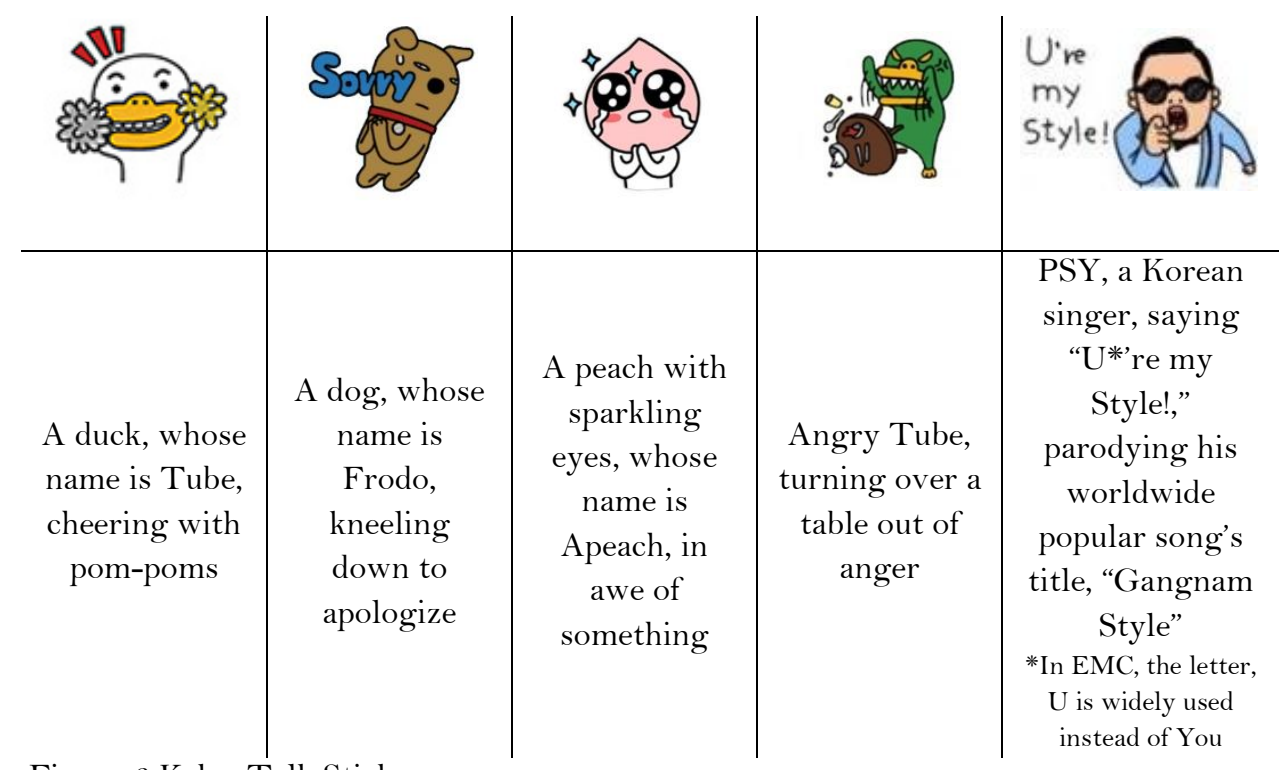

Figure 3 KakaoTalk Stickers

Emoticons are the greatest resource to channel "what the user intends by what he or she types" (Dresner and Herring 2010: 256). Emoticons, short for emotion icons, are used as nonverbal indicators of paralinguistic communication. Emoticon styles vary in form, according to Kayan, Russell, and Setlock (2006), generally consisting of special characters and letters. Emoticons are read horizontally, left to right, in western countries such as :) for a smiley face and ;) for a wink while they are read vertically, top to bottom, in eastern countries such as ${ }^{\wedge}$, which consist of two upward arrows to represent smiley eyes, and $T_{-} T$, which consist of an underline, representing a closed mouth, between two Ts, representing crying eyes. Additionally, as previously explained, in Korea, Korean letters are also used to symbolize emotion such as a crying face $T T$ or $\pi \pi$. Dresner and Herring (2010) take an account of functions of emoticons, applying speech act theory (Austin 1962, Searle 1969, 1979) in three ways: 1) emotion, mapped directly onto facial expression (e.g., happy or sad); 2) non-emotional meaning, mapped conventionally onto facial expression (e.g., a wink as indicating joking intent; an anxious smile); and 3) illocutionary force indicators that do not map conventionally onto facial 
expression (e.g., a smile as downgrading a complaint to a simple assertion) (263). By applying their findings, the following conversation will investigate how a listener, Mina, uses an animated sticker to rekey her previous message as playful in response to Dara's outing to an art museum in Korea.

\section{$\leq<$ Excerpt 11 $>>$}

Immediately preceding the following conversation, Suji, Mina, and I were chatting about how beautiful it would be to ride horses on endless plains and watch the sky full of stars at night in Mongolia. This conversation was initiated by Suji telling us she wants to travel to Mongolia while learning Mongolian (excerpt 7). Meanwhile, Dara is in Korea for her spring vacation and did not participate in the conversation at all. The excerpt begins at this point, when Dara addresses us, saying that she is about to leave for an art museum. Dara often uses 뽕 /ppyong/ [poof], instead of saying good bye in Instant Messages. 뽕 /ppyong/ [poof] is originally used by Hong Chul Roh, known as the elevator guy from PSY’s Gangnam Style music video, whenever he physically moves somewhere, which switches to another scene, as seen on the most famous Korean comedy show, 무한도전 /muhandojeon/ [Infinite Challenge].

Apr 2, 2014, 10:21 PM

야둘아.. 난 미술관간다.. 뽕...

1 Dara Guys.. I art museum go..

poof...

Guys..I am off to the gallery.. poof...

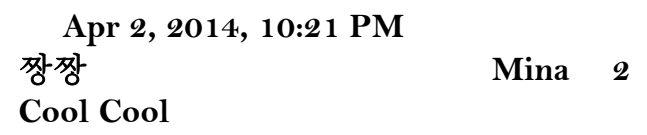

Apr 2, 2014, 10:21 PM 가서 말타고 와

Go horse-ride come Mina 3 You should go horseback 


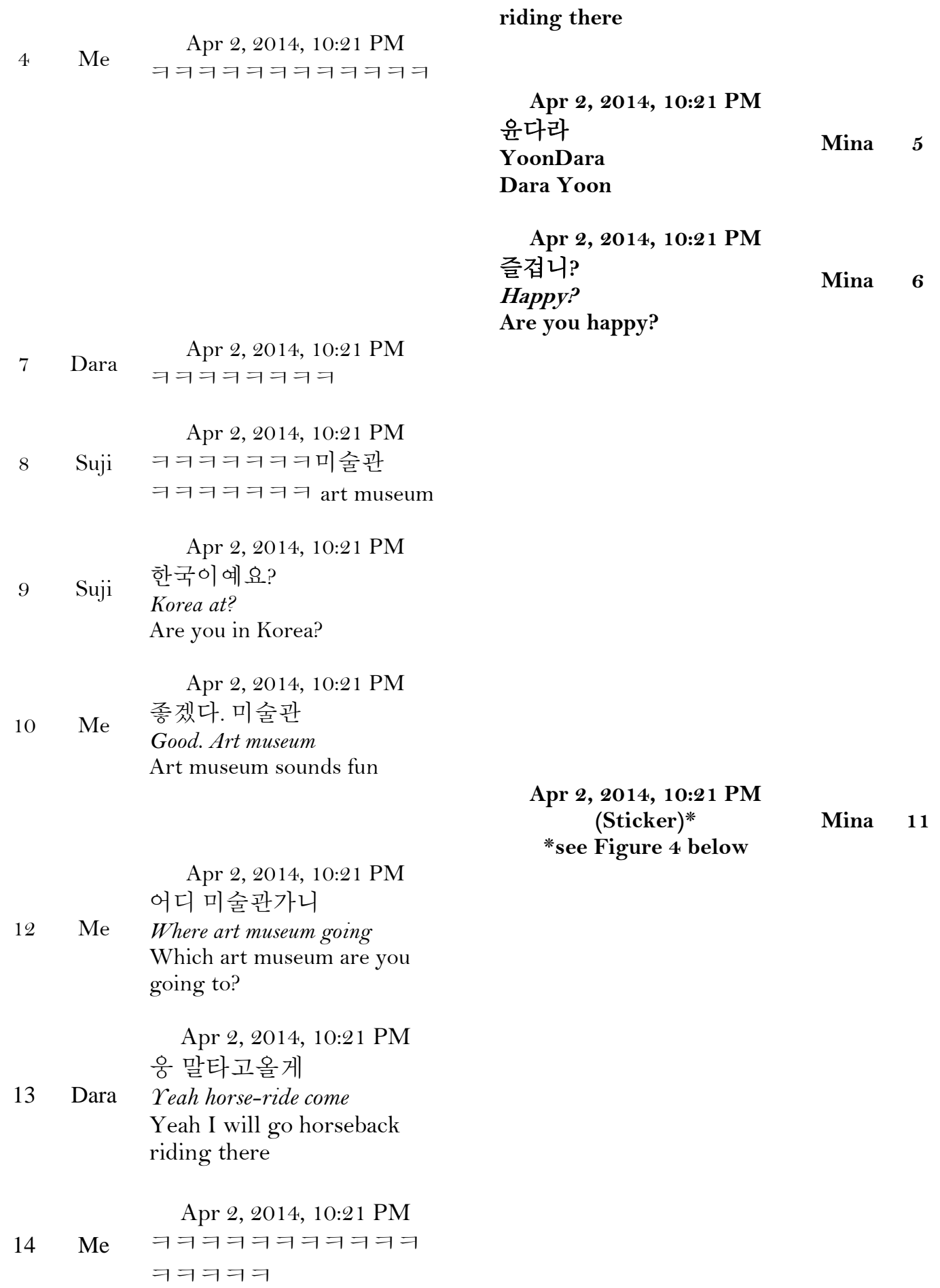




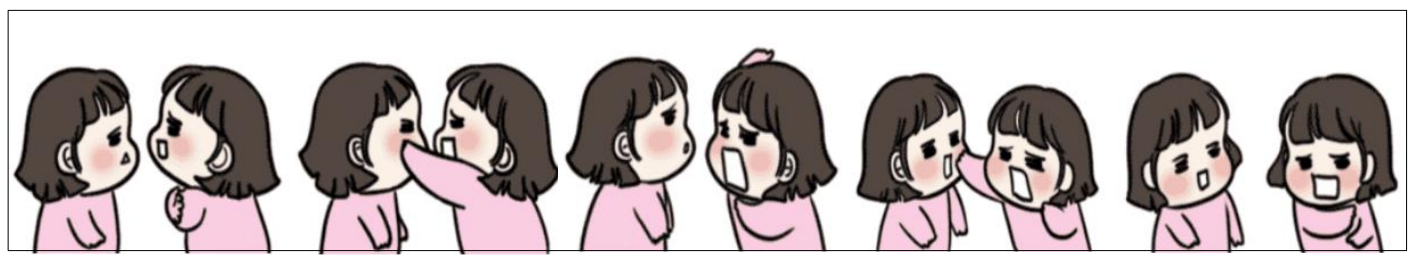

Figure 4 Slapping sticker's sequence shot used in line 11

When Dara "informs" us of her departure in line 1, "Guys...I am off to the gallery..poof...," Mina’s messages are still talking about Suji’s dream of traveling to Mongolia as seen in line 2, "Cool cool” and line 3, "You should go horseback riding there." Mina suddenly responds to Dara’s departure announcement and calls out to her in line 5, "Dara Yoon" and then in line 6, "Are you happy?" Since it is very unusual to call a person's full name between friends, Mina’s messages seem to represent her harsh jealousy and rekey the conversation as somewhat serious and upset. It could be possible that since the rest of us are studying in the U.S. while Dara is enjoying her trip to Korea, Dara’s message may annoy Mina. But, soon after, Mina sends the animated sticker in which a little girl slaps another little girl repeatedly in line 11, or Figure 4 to reveal the playfulness behind her messages, "Dara Yoon are you happy?" in lines 5 and 6. In doing so, she consequently rekeys the conversation as humorous, which is what Mina actually intends to do. The slapping sticker does not literally mean that Mina wants to slap Dara. Based on Dresner and Herring (2010), it is mapped onto the illocutionary force such that Mina's messages should not be taken seriously and are actually teasing Dara. By using the sticker, Mina demonstrates 1) that she re-aligns herself toward her previous message to elaborate her intention, which rekeys the conversation as playful and 2) that she uses the visual contextualization cue to dramatize the process of rekeying because it would not be the same at all if she simply wrote "just kidding."

The two examples have illuminated that the listener re-creates the meaning of her 
previous messages through parentheses and the sticker action by re-aligning. It suggests that there are alternative ways to take the place of phonological and paralinguistic features of contextualization cues.

\section{Chapter 6 Conclusion}

In capturing the idea that listenership is not a simple reaction to what is currently being said in discourse, this study demonstrates multiple ways of expressing listenership in Instant Messages, expanding previous studies about a range of linguistic features (repetition and minimal responses), conversational styles (machine gun questions), and situational phenomena pertaining to framing and footing. The analyses I presented have argued 1) that listeners coconstruct the interaction with speakers even in the written digital form of talk, and 2 ) that listeners reinvent and reshape features of spoken language and communication to show their listenership in Instant Messages. By introducing the concept of primary and secondary floors, this study extends the notion of listenership beyond minimal responses. Throughout my proposed floor system, I have illustrated that listenership can emerge in many different forms, including ways in which listeners can lead a conversation.

To be specific, minimal responses exploit a variety of age-based minimal responses used as support work in the form of encouragement and feedback through repetition and variation. They describe how the Korean language use is connected to relative age among socially close people. In addition, the simplified minimal response, $\bigcirc \circ$, shows how the language is reshaped by the medium, KakaoTalk. Building on Tannen’s (2005) discussion of machine gun questions, I suggest that a listener uses what I call machine gun listenership in the form of machine gun answers as well as machine gun questions to show her enthusiasm and involvement with the 
talk. Framing listenership illustrates listeners leading the conversation in various ways. In the example of reframing, the listener rekeyed the conversation as humorous by reframing it again and again. We also saw that rekeying can be accomplished in a non-phonological way. Through the example of a discursive frame shift marker, I claim that speaking and listening are discursive activities to contribute to framing phenomena and that parentheses can function as a discursive frame shift marker. Last, I showed that a listener can reveal her emotion and intentions by re-aligning toward her prior messages through parentheses and the use of a sticker as contextualization cues.

It is certainly not the case that every human being shows their listenership like this. Gender, ethnicity, language, and kinds of EMC media would change the ways people write listenership. Nonetheless, by analyzing these Instant Message conversations among five Korean female friends, I have shown how listenership is created in written digital discourse and have demonstrated that the interlocutors adapted and re-applied their language to fit the communicative setting and express their listenership. 


\section{REFERENCES}

Austin, John. 1962. How to do things with words. Cambridge, MA: Harvard University Press.

Bateson, Gregory. 1972. Steps to an ecology of mind: Collected essays in anthropology, psychiatry, evolution, and epistemology. Chicago: University of Chicago Press.

Baron, Naomi. 2004. See you online gender issues in college student use of instant messaging. Journal of Language and Social Psychology 23(4), 397-423.

Baron, Naomi, and Rich Ling. 2011. Necessary smileys and useless periods: Redefining punctuation in Electronically-Mediated Communication. Visible Language 45, 45-67.

Barron, Roderick. 1985. Interactions between spelling and sound in literacy. Literacy, language, and learning: The nature and consequences of reading and writing, ed. by Olson David, Nancy Torrance, and Angela Hildyard, 368-388. Cambridge:Cambridge University Press.

Bavelas, Janet; Linda Coates; and Trudy Johnson. 2000. Listeners as co-narrators. Journal of Personality and Social Psychology 79(6), 941-952.

Bavelas, Janet; Linda Coates; and Trudy Johnson. 2002. Listener responses as a collaborative process: The role of gaze. Journal of Communication 52(3), 566-580.

Biber, Douglas. 1988. Variation across speech and writing. Cambridge: Cambridge University Press.

Blankenship, Jane. 1974. The influence of mode, sub-mode, and speaker predilection on style. Communications Monographs 41(2), 85-118.

Borker, Ruth. 1986. Moved by the Spirit: Constructing meaning in a Brethren Breaking of Bread service. Text 6(3), 317-338.

Brenneis, Donald. 1986. Shared territory: Audience, indirection and meaning. Text 6(3), 339347.

Bublitz, Wolfram. 1988. Supportive fellow-speakers and cooperative conversations. Amsterdam: John Benjamins Publishing Company.

Castleberry, Stephen, and David Shepherd. 1993. Effective interpersonal listening and personal selling. Journal of Personal Selling \& Sales Management 13(1), 35-49.

Cayer, Roger, and Renee Sacks. 1979. Oral and written discourse of basic writers: Similarities and differences. Research in the teaching of English, 121-128.

Chafe, Wallace. 1982. Integration and involvement in speaking, writing, and oral literature. Spoken and written language: Exploring orality and literacy, ed. by Deborah Tannen, 35-53. Norwood, NJ: Ablex Publishing.

Chafe, Wallace. 1985. Linguistic differences produced by differences between speaking and writing. Literacy, language, and learning: The nature and consequences of reading and writing, ed. by Olson David, Nancy Torrance, and Angela Hildyard, 105-123. Cambridge: Cambridge University Press. 
Chafe, Wallace. 1986. Writing in the perspective of speaking. Studying writing: Linguistic approaches, ed. by Cooper Charles and Sidney Greenbaum, 12-39. Beverly Hills, CA: Sage.

Chafe, Wallace, and Deborah Tannen. 1987. The relation between written and spoken language. Annual Review of Anthropology, 383-407.

Coates, Jennier. 1986. Women, men, and language: A sociolinguistic account of sex differences in language. London, UK: Longman.

Comer, Lucette, and Tanya Drollinger. 1999. Active empathetic listening and selling success: A conceptual framework. Journal of Personal Selling Eं Sales Management 19(1), 15-29.

Couper-Kuhlen, Elizabeth. 2001. Intonation and discourse: current views from within. The handbook of discourse analysis, ed. by Deborah Schiffrin, Deborah Tannen, and Heidi Hamilton, 13-34. Malden, MA: Blackwell.

Crystal, David. 1995. Speaking of writing and writing of speaking. Online: http://www.pearsonlongman.com/dictionaries/pdfs/Speaking-Writing-Crystal.pdf.

Crystal, David. 2008. Txtng: The gr8 db8. Oxford, UK: Oxford University Press.

Danielewicz, Jane, and Wallace Chafe. 1985. How "normal" speaking leads to "erroneous" punctuating. The acquisition of written language: response and revision, ed. by Sarah Freedman, 213-225. Norwood, NJ: Ablex.

De Ruyter, Ko, and Martin Wetzels. 2000. The impact of perceived listening behavior in voice-to-voice service encounters. Journal of Service Research 2(3), 276-284.

Dresner, Eli, and Susan Herring. 2010. Functions of the nonverbal in CMC: Emoticons and illocutionary force. Communication Theory 20, 249-268.

Duranti, Alessandro. 1986. The audience as co-author: An introduction. Text 6(3), 239-247.

Edelsky, Carole. 1981. Who's got the floor?. Language in Society 10, 383-421.

Einhorn, Lois. 1978. Oral and written style: an examination of differences. Southern Journal of Communication 43(3), 302-311.

Erickson, Frederick. 1982. Money tree, lasagna bush, salt and pepper: Social construction of topical cohesion in a conversation among Italian-Americans. Analyzing discourse: Text and talk, 43-70.

Erickson, Frederick. 1986. Listening and speaking. Languages and linguistics: The interdependence of theory, data, and application, ed. by Deborah Tannen and James Alatis, 294-319. Washington, D.C.: Georgetown University Press.

Erickson, Frederick. 2004. Talk and social theory: Ecologies of speaking and listening in everyday life. Cambridge, UK: Polity Press.

Erickson, Frederick. 2010. The neglected listener: Issues of theory and practice in transcription. New adventures in language and interaction, ed. by Jurgen Streeck, 243256. Amsterdam: John Benjamins Publishing Company.

Erickson, Frederick. 2015. Personal communication. Washington, D.C. U.S.A.

Erickson, Frederick, and Jeffrey Shultz. 1982. The counselor as gatekeeper: Social interaction in interviews. Academic Press. 
Farr, Fiona. 2003. Engaged listenership in spoken academic discourse: The case of studenttutor meetings. Journal of English for Academic Purposes 2(1), 67-85.

Fasold, Ralph W. 1982. Spelling, reading, language variation. Linguistics and literacy, ed. by William Frawley, 257-268. New York, NY: Plenum.

Fellegy, Anna M. 1995. Patterns and functions of minimal response. American Speech 70(2), 186199.

Fishman, Pamela M. 1978. Interaction: The work women do. Social Problems 25(4), 397- 406.

Frier, Sarah. 2013, December 22. With \$200 Million in revenue, South Korea's top messaging app is all smiley faces. Bloomberg. Online: http://www.bloomberg.com/news/2013-1222/with-200-million-in-revenue-south-korea-s-top-messaging-app-is-all-smileyfaces.html.

Fries, Charles. 1952. The structure of English: An introduction to the construction of English sentences. New York: Harcourt, Brace.

Gardner, Rod. 1997. The conversation object Mm: A weak and variable acknowledging token. Research on Language E Social Interaction 30(2), 131-156.

Gardner, Rod. 2002. When listeners talk response tokens and listener stance. Amsterdam: John Benjamins Publishing Company.

Gardner, Rod. 2007. The right connections: Acknowledging epistemic progression in talk. Language in Society 36, 319-341.

Goffman, Erving. 1974. Frame analysis: An essay on the organization of experience. Cambridge, MA: Harvard University Press.

Goffman, Erving. 1981. Forms of talk. Philadelphia, PA: University of Pennsylvania Press.

Goodwin, Charles. 1979. The interactive construction of a sentence in natural conversation. Everyday language: Studies in ethnomethodology, 97-121.

Goodwin, Charles. 1984. Notes on story structure and the organization of participation. Structure of Social Action, ed. by Max Atkinson and John Heritage, 225-246. Cambridge: Cambridge University Press.

Goodwin, Charles. 1986. Audience diversity, participation and interpretation. Text 6(3), 283316.

Goodwin, Charles. 2000. Practices of seeing visual analysis: An ethnomethodological approach. Handbook of visual analysis, ed. by Jewitt Carey and Theo VanLeeuwen, 157-182.

Goodwin, Charles. 2002. Time in action. Current Anthropology 43(4), 19-S35.

Goodwin, Marjorie Harness. 1996. Byplay: Negotiating Evaluation in Storytelling. Towards a social science of language: Papers in honor of William Labov: Volume 2 social interaction and discourse structures, ed. by Gregory Guy, Crawford Feagin, Schiffrin Deborah, and John Baugh, 77-102. Amsterdam, PA: John Benjamins Publishing Company.

Gordon, Cynthia. 2008. A(p)parent play: Blending frames and reframing in family talk. Language in Society 37(3), 319-349. 
Gordon, Cynthia. 2009. Making meanings, creating family: Intertextuality and framing in family interaction. Oxford, UK: Oxford University Press.

Gumperz, John. 1977. Sociocultural knowledge in conversational inference. Linguistics and Anthropology 76, 785-98.

Gumperz, John. 1982. Discourse strategies: Studies in interactional sociolinguistics. Cambridge, UK: Cambridge University Press.

Gumperz, John. 2001. Interactional sociolinguistics: A personal perspective. The handbook of discourse analysis, ed. by Deborah Schiffrin, Deborah Tannen, and Heidi Hamilton, 215228. Malden, MA: Blackwell.

Hall, Edward. 1969. Listening behavior: Some cultural differences. Early Childhood Education $50(7), 379-380$.

Haviland, John. 1986. Con buenos chiles: Talk, targets, and teasing in Zinacantan. Text 6(3), 249-282.

Heritage, John. 1984. A change-of-state token and aspects of its sequential placement. Structures of social action, ed. by Maxwell Atkinson and John Heritage, 299-345. Cambridge, UK: Cambridge University Press.

Hiyashi, Reiko. 1991. Floor structure of English and Japanese conversation. Journal of Pragmatics 16, 1-30.

Horowitz, Milton, and Allan Berkowitz. 1964. Structural advantage of the mechanism of spoken expression as a factor in differences in spoken and written expression. Perceptual and motor skills 19(2), 619-625.

Horowitz, Milton, and John Newman. 1964. Spoken and written expression: An experimental analysis. The Journal of Abnormal and Social Psychology 68(6), 640.

Jefferson, Gail. 1984. Notes on a systematic deployment of the acknowledgement tokens "yeah" and "mm hm". Papers in Linguistics 17, 197-216.

Jones, Rod, and Joanna Thornborrow. 2004. Floors, talk and the organization of classroom activities. Language in Society 33, 399-423.

Kayan, Shipra; Susan Fussell; and Leslie Setlock. 2006. Cultural differences in the use of instant messaging in Asia and North America. Paper presented at the ACM conference on Computer Supported Cooperative Work, 525-528.

Kim, Young Chul. 2005. Urimal damhwa pyoji 'Ah' aochal. [A study on 'Ah', a discourse marker in Korean language]. Kukeumunhak 40, 161-174.

Kellerman, Susan. 1992. 'I see what you mean': The role of kinesic behaviour in listening and implications for foreign and second language learning. Applied Linguistics 13(3), 239258.

Kendall, Shari. 2006. 'Honey, I'm home!': Framing in family dinnertime homecomings. Text $\mathfrak{E}^{\circ}$ Talk 26(4/5), 411-441. 
Kendon, Adam. 1990. Behavioral foundations for the process of frame-attunement in face-toface interaction. Conducting interaction: Patterns of behavior in focused encounters, ed. by Adam Kendon, 239-262. Cambridge, UK: Cambridge University Press.

Ko, Kwang Kyu. 1996. Structural characteristics of Computer-Mediated Language: A comparative analysis of interchange discourse. Electronic Journal of Communication/La Revue Electronique de Communication 6 (3). Online: http://www.cios.org/EJCPUBLIC/006/3/006315.HTML

Labov, William, and David Fanshel. (1977). Therapeutic discourse: Psychotherapy as conversation. New York: Academic Press.

Li, Han Z. 2006. Backchannel responses as misleading feedback in intercultural discourse. Journal of Intercultural Communication Research 35(2), 99-1 16.

Maltz, Daniel, and Ruth Borker. 1982. A cultural approach to male-female miscommunication. Language and social identity, ed. by John Gumperz, 195-216. Cambridge, UK: Cambridge University Press.

Maynard, Senko. 1990. Conversation management in contrast: Listener response in Japanese and American English. Journal of Pragmatics 14(3), 397-412.

McCarthy, Michael. 1996. Good listenership made plain: British and American nonminimal response tokens in everyday conversation. Using corpora to explore linguistic variation, ed. by Randi Reppen, Susan Fitzmaurice, and Douglas Biber, 49-72. Amsterdam: John Benjamins Publishing Company.

Meyerhoff, Miriam. 1994. Sounds pretty ethnic, eh?: A pragmatic particle in New Zealand English. Language in Society 23, 367-388.

Murphy, Brona. 2012. Exploring response tokens in Irish English-a multidisciplinary approach: Integrating variational pragmatics, sociolinguistics and corpus linguistics. International Journal of Corpus Linguistics 17(3), 325-348.

Nunan, David. 2002. Listening in language learning. Methodology in language teaching: An anthology of current practice, 238-241.

Ochs, Elinor. 1979. Planned and unplanned discourse in discourse and syntax. Syntax and Semantics 12, 51-80.

Ramsey, Rosemary, and Ravipreet Sohi. 1997. Listening to your customers: The impact of perceived salesperson listening behavior on relationship outcomes. Journal of the Academy of Marketing Science 25(2), 127-137.

Richardson, Daniel, and Rick Dale. 2005. Looking to understand: The coupling between speakers' and listeners' eye movements and its relationship to discourse comprehension. Cognitive Science 29(6), 1045-1060.

Rosenfeld, Howard. 1966. Approval-seeking and approval-inducing functions of verbal and nonverbal responses in the dyad. Journal of Personality and Social Psychology 6, 597-605.

Rost, Michael. 2013. Listening in language learning. New York, NY: Routledge. 
Sacks, Harvey; Emanuel Schegloff; and Gail Jefferson. 1974. A simplest systematics for the organization of turn-taking for conversation. Language, 696-735.

Schegloff, Emanuel. 1972. Sequencing in conversational openings. Directions in Sociolinguistics: The ethnography of communication, ed. by John Gumperz and Dell Hymes, 346-380. New York: Holt.

Schegloff, Emanuel. 1982. Discourse as an interactional achievement: Some use of "uh-huh" and other things that come between sentences. Analyzing discourse: Text and talk, ed. by Deborah Tannen, 71-93. Washington, DC: Georgetown University Press.

Schiano, Diane; Coreena Chen; Ellen Isaacs; Jeremy Ginsberg; Unnur Gretarsdottir; and Megan Huddleston. 2002. Teen use of messaging media. Paper presented at CHI 'O2 Human Factors in Computing Systems, 594-595.

Searle, John. 1969. Speech acts: An essay in the philosophy of language. Cambridge, UK: Cambridge University Press.

Searle, John. 1979. Expression and meaning: Studies in the theory of speech acts. Cambridge, UK: Cambridge University Press.

Shultz, Jeffrey; Susan Florio; and Frederick Erickson. 1982. Where's the floor?: Aspects of the cultural organization of social relationships in communication at home and at school. Ethnography and education: Children in and out of school, ed. by Perry Gilmore and Allan Glatthorn, 88-123. Washington, DC: Center for Applied Linguistics.

Song, Jae Jung. 2005. The Korean language: Structure, use and context. London, UK: Routledge.

Tannen, Deborah. 1982. The oral/literate continuum in discourse. Spoken and written language: Exploring orality and literacy, ed. by Deborah Tannen, 1-16. Norwood, NJ: Ablex Publishing.

Tannen, Deborah. 1990. Tou Just Don't Understand: Women and men in conversation. New York: Morrow.

Tannen, Deborah. 1993. Framing in discourse. New York: Oxford University Press.

Tannen, Deborah. 2005. Conversational Style: Analyzing talk among friends. New York: Oxford University Press.

Tannen, Deborah. 2006. Intertextuality in interaction: Reframing family arguments in public and private. Text E Talk 26(4/5), 597-617.

Tannen, Deborah. 2007. Talking voices: Repetition, dialogue, and imagery in conversational discourse. Cambridge, UK: Cambridge University Press.

Tannen, Deborah. 2013. The medium is the metamessage: Conversational style in new media interaction. Discourse 2.0: Language and new media, ed. by Deborah Tannen and Anna Trester, 99-117. Washington, DC: Georgetown University Press.

Tannen, Deborah, and Cynthia Wallat. 1987. Interactive frames and knowledge schemas in interaction: Examples from a medical examination/interview. Social Psychology Quarterly 50(2), 205-216. 
Whiteman, Farr. 2013. Writing: The nature, development, and teaching of written communication. Routledge.

Werry, Christopher. 1996. Linguistic and interactional features of Internet Relay Chat.

Computer-mediated communication: Linguistic, social, and cross-cultural perspectives, ed. by Susan Herring, 47-63. Amsterdam: John Benjamins Publishing Company.

West, Laura, and Anna Trester. 2013. Facework on Facebook: Conversations on social media. Discourse 2.0: Language and new media, ed. by Deborah Tannen and Anna Trester, 133154. Washington, DC: Georgetown University Press.

Xudong, Deng. 2009. Listener response. The pragmatics of interaction 4, 104-124.

Yngve, Victor H. 1970. On getting a word in edgewise. Papers from the 6th regional meeting of the Chicago Linguistic Society, 567-578.

Young, Richard, and Jina Lee. 2004. Identifying units in interaction: Reactive tokens in Korean and English conversations. Journal of Sociolinguistics 8(3), 380-407. 